Florida International University FIU Digital Commons

4-1-2011

\title{
Development of a New Student Evaluation Instrument of Instructor Effectiveness in Online Courses
}

Fernando J. Ganivet

Florida International University, ganivetf@fiu.edu

DOI: $10.25148 /$ etd.FI1 1042603

Follow this and additional works at: https://digitalcommons.fiu.edu/etd

\section{Recommended Citation}

Ganivet, Fernando J., "Development of a New Student Evaluation Instrument of Instructor Effectiveness in Online Courses" (2011). FIU Electronic Theses and Dissertations. 382.

https://digitalcommons.fiu.edu/etd/382 


\section{FLORIDA INTERNATIONAL UNIVERSITY}

Miami, Florida

\section{DEVELOPMENT OF A NEW STUDENT EVALUATION INSTRUMENT OF INSTRUCTOR EFFECTIVENESS IN ONLINE COURSES}

A dissertation submitted in partial fulfillment of the requirements for the degree of DOCTOR OF EDUCATION

in

HIGHER EDUCATION

by

Fernando Ganivet

2011 
To: Dean Delia C. Garcia

College of Education

This dissertation, written by Fernando Ganivet, and entitled Development of a New Student Evaluation Instrument of Instructor Effectiveness in Online Courses, having been approved in respect to style and intellectual content, is referred to you for judgment.

We have read this dissertation and recommend that it be approved.

Benjamin Baez

Thomas Reio

M. O. Thirunarayanan

Leonard B. Bliss, Major Professor

Date of Defense: April 1, 2011

The dissertation of Fernando J. Ganivet is approved.

Dean Delia C. Garcia

College of Education

Interim Dean Kevin O'Shea

University Graduate School 
(C) Copyright 2011 by Fernando Ganivet

All rights reserved. 


\section{DEDICATION}

I dedicate this dissertation to my wife, who has shown more patience than I had a right to ask for. Without her support, the completion of this project would simply not have been possible. 


\section{ACKNOWLEDGMENTS}

I would be remiss without thanking the members of my committee for their support, and always timely advice.

To Dr. Benjamin Baez, who set me straight about what I needed to accomplish in chapter 5, and kept me out of trouble at that difficult stage.

To Dr. M. O. Thirunarayanan, who made me aware of something crucial I had missed in the literature that possibly would have come back to haunt me later.

To Dr. Thomas Reio, whose incisive and organized mind provided valuable organizational advice and suggestions for further development of ideas.

To my major professor, Dr. Leonard B. Bliss, who had unwavering faith in me throughout these trying times, and truly became my mentor.

Finally, to Dr. Linda Bliss, who volunteered to read my first three chapters prior to my proposal defense, helping me to both clarify ideas and to keep my style uncorrupted. 


\title{
ABSTRACT OF THE DISSERTATION \\ DEVELOPMENT OF A NEW STUDENT EVALUATION INSTRUMENT \\ OF INSTRUCTOR EFFECTIVENESS IN ONLINE COURSES
}

\author{
by
}

Fernando Ganivet

Florida International University, 2011

Miami, Florida

Professor Leonard B. Bliss, Major Professor

The purpose of this study was to (a) develop an evaluation instrument capable of rating students' perceptions of the instructional quality of an online course and the instructor's performance, and (b) validate the proposed instrument with a study conducted at a major public university. The instrument was based upon the Seven Principles of Good Practice for Undergraduate Education (Chickering \& Gamson, 1987). The study examined four specific questions.

1. Is the underlying factor structure of the new instrument consistent with Chickering and Gamson's Seven Principles?

2. Is the factor structure of the new instrument invariant for male and female students?

3. Are the scores on the new instrument related students' expected grades?

4. Are the scores on the new instrument related to the students' perceived course workload?

The instrument was designed to measure students' levels of satisfaction with their instruction, and also gathered information concerning the students' sex, the expected 
grade in the course, and the students' perceptions of the amount of work required by the course. A cluster sample consisting of an array of online courses across the disciplines yielded a total 297 students who responded to the online survey. The students for each course selected were asked to rate their instructors with the newly developed instrument.

Question 1 was answered using exploratory factor analysis, and yielded a factor structure similar to the Seven Principles.

Question 2 was answered by separately factor-analyzing the responses of male and female students and comparing the factor structures. The resulting factor structures for men and women were different. However, 14 items could be realigned under five factors that paralleled some of the Seven Principles. When the scores of only those 14 items were entered in two principal components factor analyses using only men and only women, respectively and restricting the factor structure to five factors, the factor structures were the same for men and women.

A weak positive relationship between students' expected grades and their scores on the instrument was found (Question 3). There was no relationship between students' perceived workloads for the course and their scores on the instrument (Question 4). 


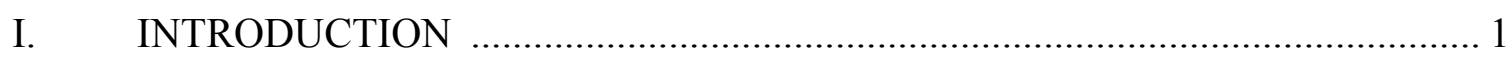

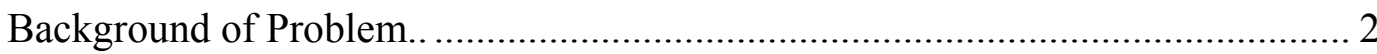

The Seven Principles............................................................................................ 4

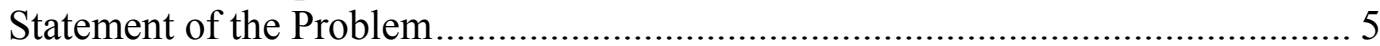

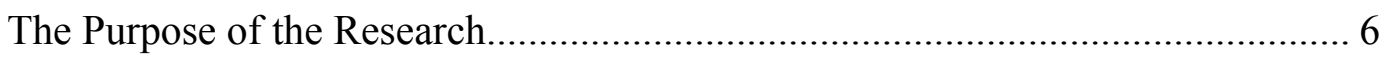

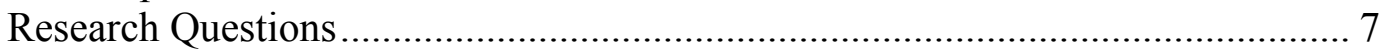

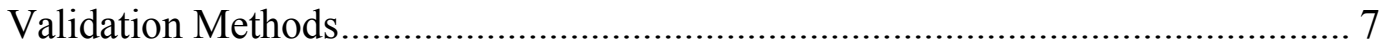

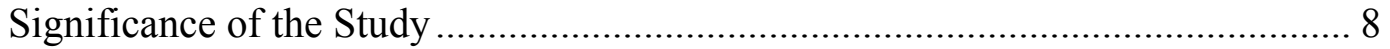

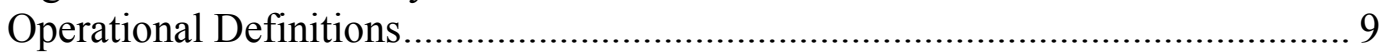

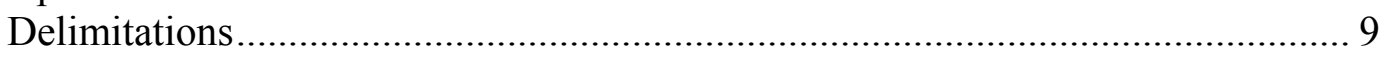

II. REVIEW OF THE LITERATURE ……….............................................. 10

The Rationale for Student Evaluations of Facuty ................................................ 10

Students as Evaluators of Teaching Effectiveness............................................. 13

The Seven Principles............................................................................................ 16

The Role of the Seven Principles in Online Courses .............................................. 40

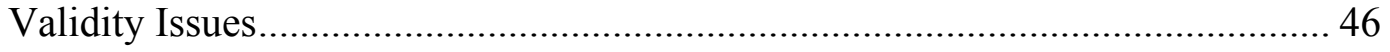

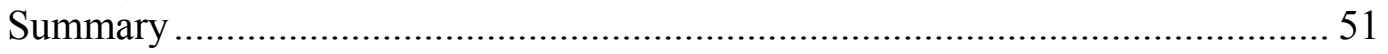

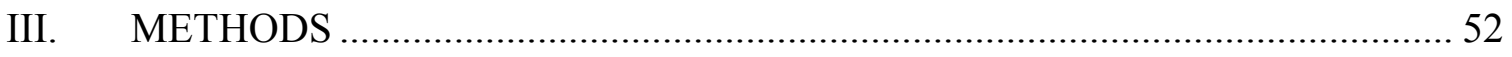

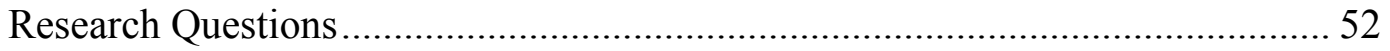

Sample

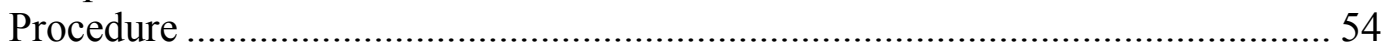

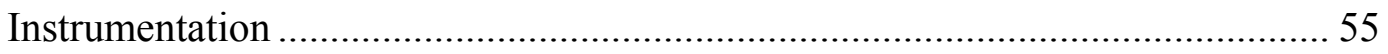

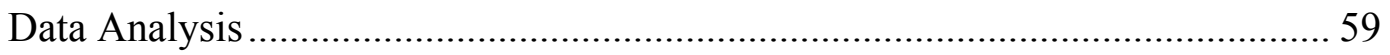

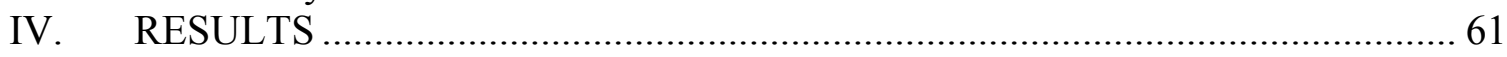

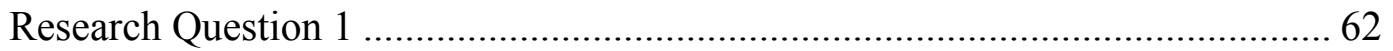

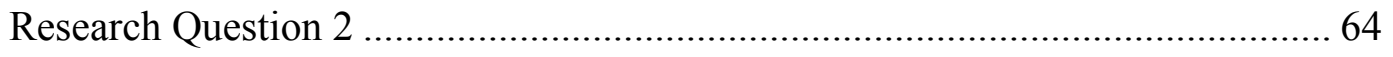

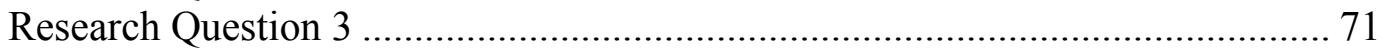

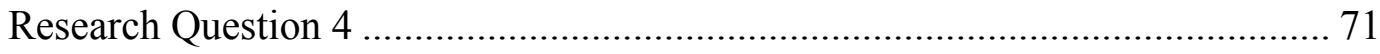

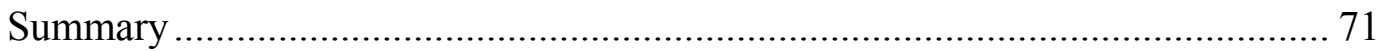

V. DISCUSSION AND RECOMMENDATIONS................................................. 73

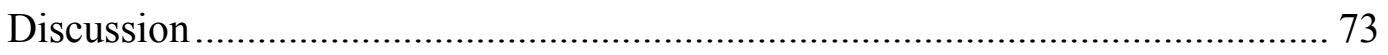

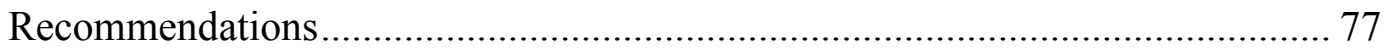

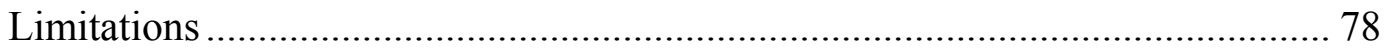

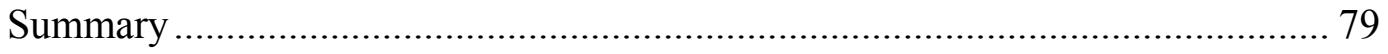

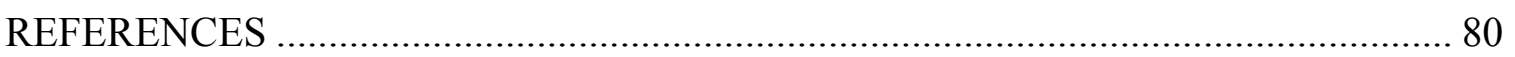


APPENDICES .

VITA 100 


\section{CHAPTER I}

\section{INTRODUCTION}

The purpose of this study was to (a) develop an alternative evaluation instrument capable of rating students' perceptions of the instructional quality of an online course and the instructor's performance, and (b) validate the proposed instrument with a study conducted at a major public university in Florida. The instrument is based upon the Seven Principles of Good Practice for Undergraduate Education (Chickering \& Gamson, 1987), as operationalized by Graham, Cagiltay, Lim, Craner, and Duffy (2001), and Phipps and Merisotis, (2000). The underlying structure of the instrument was identified by factor analysis from the data obtained when the instrument was administered to a sample of students taking undergraduate-level online courses.

Online distance education now comprises a significant portion of the higher education course offerings throughout the nation. Over 5.6 million students were enrolled in at least one college-level online course during the fall 2009 term (Allen \& Seaman, 2010). Online learning is defined as a course that delivers most of the contents online, typically without face-to-face meetings (Allen \& Seaman, 2005). This dissertation developed and validated an instrument for assessing teaching performance as perceived by students in asynchronous Internet-based distance education courses.

Teaching online in an asynchronous mode differs radically from what takes place in a classroom where instructor and student are simultaneously present. From the nature of the interaction between instructor and student, to the delivery of course content, there are vast differences between the processes used in a traditional classroom and an electronic classroom. Thus, customary instruments used for the evaluation of traditional 
courses, such as the various Student Rating of Teaching Effectiveness (SRTE's)

instruments currently in use, which have questionable validity even when used in regular courses, are even more problematic as an accurate assessment of the perceived quality of instruction in courses that are taught online. Knapper (2001) argued that current evaluation methods are inappropriate for the newer instructional contexts, such as online teaching.

Phipps and Merisotis (2000) are among those who argued that teaching online is fundamentally different from what takes place in a traditional classroom, having pointed out that in asynchronous courses instructors are not only separated by distance from students, but also by time because the students typically access the course at their convenience; thus, requiring a different set of quality benchmarks for evaluating the role of the instructor. In the same vein, Theall and Franklin (2000) argue that the student ratings collected with instruments that are used for traditional classroom do not address the unique characteristics of the on-line teaching and learning situation and, therefore, are not designed to collect data about the alternative teaching methods that are typically used in the online medium.

\section{Background of the Problem}

Although models of student evaluations of faculty performance abound in the literature, the body of research focusing upon online faculty evaluations is not nearly as extensive. Chiefly among the pioneers of online instruction research are Graham et al. (2001), who used an instrument modeled upon Chickering and Gamson's (1987) Seven Principles of Good Practice in Undergraduate Education, as the basis for a pilot study evaluating several online courses at a major university. Their objective was to identify 
how the seven principles were manifested in those online courses through a review of the online course materials, a compilation of the student and instructor discussion-forum postings, and interviews with the instructors. The study, while limited in size, identified a list of discrete instructor behaviors that correspond with each of Chickering and Gamson's seven principles.

In the same vein, in a study commissioned by the National Education Association, Phipps and Merisotis (2000) examined the online programs at six institutions that were considered leaders in Internet-based education, and identified a set of quality assurance benchmarks that are common to good online programs, including seven that specifically address the course design and teaching processes. Six of those benchmarks correlate with six of the seven processes identified by Graham et al. (2001). These two studies operationalized the principles of good practice outlined by Chickering and Gamson, (1987) and served as the basis for an emerging body of literature that has focused upon the interaction between student and instructor, and among students, in online courses. This literature, however, presents a picture that is far from clear. It lacks consistency other than to generally agree that interaction is a necessary component of online teaching.

Because there appears to be general agreement as to the necessity of interaction between students and instructors in online instruction, it seems likely that designers of online instruction would include opportunities for this type of interaction in their courses. Those who produce evaluation instruments for these courses should keep in mind the literature concerning students' perceptions of faculty performance. This literature indicates that these interactions between students and faculty affect the validity of inferences made from data obtained through the use of those instruments. That 
assumption has been shown to be true for traditional classroom instruction and is very likely to be true for online instruction. Three variables that may affect student-faculty interactions are (a) the sex of the student, (b) the sex of the instructor (Basow \& Montgomery, 2005), and (c) perceived instructor leniency, which includes course workload and expected grade (Greenwald \& Gilmore, 1997).

\section{The Seven Principles}

The Seven Principles of Good Practice in Undergraduate Education (Chickering \& Gamson, 1987) was originally published more than 20 years ago and have withstood the test of time. The Seven Principles comprise a concise inventory of best pedagogical practices, as follows:

1. Encourages contacts between students and faculty.

2. Develops reciprocity and cooperation among students.

3. Uses active learning techniques.

4. Gives prompt feedback.

5. Emphasizes time on task.

6. Communicates high expectations.

7. Respects diverse talents and ways of learning.

Although the idea was born in 1985 during a board meeting of the American Association for Higher Education (AAHE), it was largely a continuation of the work accomplished by the National Institute of Education's (NIE) Study Group on the Conditions of Excellence in American Higher Education. The final and widely circulated report of the Study Group was entitled, Involvement in Learning: Realizing the Potential of American Higher Education (1984). The findings of that report provided the starting 
point for the ensuing discussions that took place at the Wingspread conference center at Racine, Wisconsin, in July 1986.

Although the final document was authored by Chickering and Gamson, it reflected the collective wisdom of some of the leading researchers from that time, who continued the dialogue begun at Wingspread after dispersing again to their respective institutions (Chickering \& Gamson, 1999). The goal of the Wingspread group was to create a universal set of good teaching practices based upon an extensive review of the teaching and learning research literature of the 1980 s that could be easily implemented by any faculty member. The result was the document that concisely describes a total of seven good teaching practices in undergraduate education (Chickering \& Gamson, 1987).

\section{Statement of the Problem}

Most online courses at institutions of higher education are routinely evaluated by participating students as part of the institutional quality assurance objectives. However, it can be argued that the existing instruments are deemed less than satisfactory by a significant number of the administrators who are in charge of the distance education programs. In a study conducted with the administrators of distance education programs at the 28 Florida public community colleges (Ganivet, 2002), 95\% of the respondents $(n=22)$ indicated that they could benefit from a new instrument for evaluating distance education faculty. Moreover, $77 \%$ of the respondents believed that the issue was important enough to volunteer their time and talents in the development and testing of such a model.

Although several institutions have adapted instruments for the online medium in the intervening years, there is still considerable interest in an instrument that has a sound 
theoretical basis, and that has been appropriately validated. Furthermore, many institutions tend to use the data from the student evaluation of faculty performance instruments for two entirely different but equally crucial purposes (Arreola, 2000; Redmon, 1999). The first one is for formative evaluations that are commonly used as a tool that assists the professional development of faculty members, by providing a basis for constructive feedback that will help improve their teaching performance. The other side of the coin is the summative or performance evaluation, which is judgmental in nature and is typically used by administrators for the purpose of making personnel decisions, such as the continuation or termination of an untenured faculty member. Redmon (1999) maintained that both procedures are institutionally necessary to some extent, and that they may be methodically reconciled in an instrument that serves both needs. Moreover, Campion, Mason and Erdman (2000) argued that institutions must implement a faculty assessment system that incorporates both summative and formative evaluations if they are to comply with the accrediting agencies such as the Southern Association of Colleges and Schools (SACS). Thus, a practical evaluation instrument should incorporate elements of both.

\section{The Purpose of the Research}

The purpose of this research was to devise and validate an instrument for student evaluation of online courses. In addition, the study determined whether men and women responded to the instrument in a similar manner, and whether there is a relationship between the sex of the respondent and the respondent's perception of the amount of work required in the course and the respondent's rating of the course. 


\section{Research Questions}

The study will seek answers to the following questions:

1. Is the underlying factor structure of the new instrument consistent with the Chickering and Gamson's (1987) Seven Principles?

2. Is the factor structure of the new instrument invariant for male and female students?

3. Are the scores on the new instrument related to the grades that the students expect in the course?

4. Are the scores on the new instrument related to the students' perceived workload in the course?

\section{Validation Methods}

The Seven Principles (Chickering \& Gamson, 1987) provide a concise inventory of teaching practices that ostensibly contribute to student learning, and that are at the same time suitable for a classroom evaluation instrument. Thus, in theory, each item in the instrument based on the Seven Principles provides an operational definition for the construct, "effective teaching," because the items comprise constructive behaviors (i.e., behaviors that facilitate student learning) on the part of the instructor, that are observable by the students.

Chatterji (2003) provided a basic systematic process model for assessment, design, selection, and validation of the items in a measuring instrument, which applies to a variety of scenarios, with some modifications within the model's four phases. In addition, this process would be useful for validating both formative and summative evaluation instruments. Phase I consists of defining the construct, population, and purpose. In Phase II the procedural specifications are developed according to the 
definitions accomplished in Phase I, such as scaling and scoring. In Phase III of the process, rules and guidelines are selected and applied to the construction of the items, culminating with scoring rules. Phase IV is the validation stage.

\section{Significance of the Study}

The results of the study could have significance for faculty as well as administrators. A valid new instrument will better address the formative needs of faculty, by identifying and ranking those processes that students consider more conducive to learning. First, the results can be integrated in faculty workshops to improve online teaching effectiveness. Namely, the results may be categorized and developed into specialized workshops, as a way to coach faculty members on techniques that may lead to higher student satisfaction ratings, which may be particularly important for yet untenured faculty members whose classroom ratings will likely come under scrutiny.

Second, the results will better address the summative needs of institutions, by eliminating some of the ambiguity associated with pure satisfaction surveys, focusing instead on the presence or absence of specific processes in the online teaching environment. Furthermore, the results will help the institutions comply with the accreditation guidelines that have been specifically formulated for online courses, by providing an instrument that is better aligned with widely promulgated quality benchmarks, that is, the Seven Principles.

Third, the results of the study and the items in the instrument should be useful as research tools for future studies of teaching performance as perceived by the students, and should also add evidence to the validity issues that have been raised in the 
inconclusive body of literature on student-instructor gender effects, and perceived instructor leniency effects, on student evaluations of faculty.

\section{Operational Definitions}

\section{Effective Teaching}

Effectiveness of teaching will be measured by the scores of the participants on the instrument derived from Chickering and Gamson's (1987) Seven Principles.

\section{Expected Grade}

The grade that the participant expects to receive in the course in which the instructor is being evaluated will be determined by the participant's response to item number 30 of the Online Teaching Effectiveness Instrument (see appendix).

\section{Workload}

The level of assigned workload perceived by the students in the course in which the instructor is being evaluated will be determined by the participants' response to item number 29 of the Online Teacher Effectiveness instrument.

\section{Delimitations}

Participants responding to the instrument will have taken online courses at Florida International University during the Fall 2009 semester.

1. Only undergraduate online courses will be used in this study.

2. Data obtained in this study will be strictly the result of participant self report. No attempt to observe or collect information from any other source.

3. Participation in the study was strictly on a voluntary basis. 


\section{CHAPTER II}

\section{REVIEW OF THE LITERATURE}

The practice of having college students report their perception of the quality of their instructors has grown steadily since the 1960's educational reform movement and has remained a controversial topic with college faculty to this day. Moreover, as we enter the twenty-first century, student evaluations of their instructors have become such an integral part of the higher education landscape that the college or university that does not regularly provide such a rating instrument to its students would not only be considered atypical, but could also lose its accreditation if unable to substantiate adequate student satisfaction with the programs.

\section{The Rationale for Student Evaluations of Faculty}

The most common reason given for having college students evaluate the teaching performance of their instructors is that the feedback helps faculty members improve their teaching, which was the original reason for conducting those evaluations at most American institutions (Centra, 1993; Ory, 2000). In reality, that original purpose has evolved over the years and institutions now benefit from student evaluations of faculty in other ways.

Beyond the constructive purpose originally envisioned, administrators often use the data derived from those evaluations these days for other purposes, such as to mitigate the public pressure for increased accountability, to validate compliance with accreditation agency criteria, and to inform personnel decisions. Accordingly, the nature of the instruments used and the number of questions they contain have been altered to the changing needs of the institution, as perceived by administrators. As Ory (2000) 
observed, the objectives of student evaluations of faculty have been in a constant state of change, simply because they have had to address the interests of a number of different audiences during the last few decades.

For example, the pressure groups that were advocating increased teacher accountability for student learning can be deemed instrumental in institutionalizing the practice of student evaluations of faculty in Florida's public universities. In 1999 the State of Florida Board of Regents mandated the use of student evaluations throughout the state university system (Herbert, 1999), directing that every course taught be evaluated, requiring that those evaluations become part of the overall performance evaluation of individual faculty members, and at the same time opening the resulting data to public scrutiny. Herbert noted that, in this case, the Regents were reacting to political pressure from the educational reform movement by making individual faculty members more accountable to the public.

The institutions' continuing needs for instructor evaluations are also dictated by other administrative concerns. As Campion (2000) noted, the Southern Association of Colleges and Schools (SACS) also mandates periodic evaluations of the performance of faculty members for formative purposes, as part of their accreditation criteria. Thus, institutions are routinely required to compile student satisfaction data as part of the SACS compliance process. Nonetheless, in spite of their purportedly benign intent, faculty members are often justified in feeling threatened by those evaluations, in spite of their constructive potential. For example, Algozzine et al. (2004) cautioned that their research data indicated that student satisfaction surveys are often too heavily--and probably unfairly--relied upon as summative assessment tools. The researchers cite the all-too- 
frequent reliance upon student ratings by tenure committees and administrators, as the primary measure of teaching effectiveness, when making important personnel decisions, such as granting tenure and promotions.

Although the question of the fairness of utilizing the same data for both formative and summative evaluations has generated much controversy over the years, a significant number of researchers endorse their dual use, albeit with some important caveats. For example, Miller (1987) stressed that although there is nothing wrong with using the same data for both formative and summative purposes, there is no such thing as an all-purpose instrument; therefore, every reasonable precaution must be taken to weigh both the validity and reliability of each item against the perceived need, in the interest of fairness to all parties concerned.

In a different vein, Centra (1993) recommended that if the student evaluations are to be used for both purposes, fairness dictates that they should first be employed for strictly formative feedback, so that the instructors can become familiar with the evaluation criteria before they are actually rated by the students for summative purposes. On the other hand, Algozzine et al. (2004) cautioned against using across the board comparisons, such as questions that ask students to rate "overall" performance, when those will be used by administrators for the purpose of making personnel decisions. Instead, they recommend a careful selection of the data to be utilized, based on a judicious assessment of the rationale for including each item on the questionnaire.

Thus, this study developed and validated what should be more accurate indicators of teaching effectiveness, as compared to the broader questions that are typically asked from the students on current teaching evaluation instruments. To this end, the instrument 
focused upon the classroom processes that are aligned with the Seven Principles, and that are widely believed to promote student learning.

\section{Students as Evaluators of Teaching Effectiveness}

A recurring question that the critics of classroom evaluations raise is whether students are qualified to assess the competency of the instructor. Realistically, the response to that question is linked to the philosophical perspectives that define the role of the instructor in the classroom.

To that end, Arreola (2000) defined three theoretical perspectives of what an instructor's responsibility is with regard to the students' learning. The first notion conceptualizes teaching as simply providing an opportunity for the students to learn. Thus, the defining factor of teaching competence in that context is content expertise, with the teacher adopting the role of sage, as both knowledge transmitter and mentor. Consequently, accepting content knowledge as the operational criteria for teaching competence would imply that students would not be qualified to evaluate their teacher, because only a peer could truly evaluate subject matter knowledge.

The second viewpoint described by Arreola (2000) portrays the role of the teacher as a facilitator who possesses some beneficial personal attributes that would motivate students to learn. In this case, students would presumably be capable of evaluating the teacher, although on a very limited basis. Thus, in terms of evaluating teaching effectiveness, students would be restricted to answering questions that would determine the extent of their perceptions of learning, primarily in terms of their own level of interest in the course. 
In the third model, the teacher becomes responsible for implementing processes that cause the students to learn. Arreola (2000) argued that in that case, teaching effectiveness could only be logically ascertained with a post-test that would measure how much the students have actually learned. Thus, only in the second model would the students' opinions carry weight.

In a similar vein, Sheehan and DuPrey (1999) argued that students' selfassessments of the learning that has taken place in a course are not suitable measurements for faculty evaluations. Because most instruments that measure instructor effectiveness are solely intended to measure student perceptions, it follows that assessments of their own learning would only be subjective, and would be likely to result in inaccurate measurements of actual learning. Moreover, data on actual student achievement is rarely collected and correlated with the student surveys. This reinforces the notion that only judgments about the affective domain remain within students' area of competence, and this view is fairly prevalent throughout the literature.

In light of that, Miller (1987) advocates limiting the evaluation instruments intended for the students to specific questions about what they have experienced in the classroom. In a similar vein, Dilts, Haber and Bialik (1994) acknowledge that there are many dimensions of teaching that students simply cannot evaluate, and generally agree that the affective domain would be the most legitimate area for the students to evaluate. Consequently, with student evaluations of faculty performance, the questions would need to be limited to what the students themselves could reasonably ascertain; namely, those actions that they perceive as somehow facilitating their learning experience or making it more agreeable. 
As a result, some researchers have focused upon identifying specific behaviors that have consistently been perceived as good teaching practices by the students. In their metanalysis of student evaluation literature, Sheehan and DuPrey (1999) stated that their scrutiny of a multitude of classroom instruments identified five strong predictors of success for the instructor. Two of those five instructor characteristics that displayed a strong correlation with perceived teaching effectiveness were that their lectures were informative and that their lectures were interesting. The third one was to the effect that the instructor appeared well-prepared. Thus, these findings tend to confirm that effective teaching, at least as perceived by the students, is largely a matter of facilitating learning, and perhaps more important, of somehow motivating the students to learn. Consequently, the teaching style displayed by the instructor should have considerable influence on a student's perceptions of his or her effectiveness.

Then there are social forces to consider. Ewell and Jones (1996) insisted that public pressure has shifted the focus of accountability in higher education from input measures, such as resources and expenditures, to process measures, as in the actual delivery of instruction. Furthermore, teaching effectiveness models in higher education have been increasingly coupled with ostensibly successful processes in business because they parallel those employed in the prevailing business models, such as total quality management (Gates, Augustine \& Benjamin, 2002). Thus, a majority of the stakeholders who call for more teacher accountability, from politicians to the general public, should easily accept process measurements as rational and comprehensible.

However, finding a sound, time-tested set of classroom best practices can become a challenge because education in general is a discipline fraught with fads. More to the 
point, Maddux and Cummings (2004) argued that practitioners in education have more of a propensity to adopt short-lived trends than most other disciplines, and that the reason why most of those fads are abandoned is because they lack a sound theoretical basis. Although that is a generalization about the practice of education at all levels, and probably truer of elementary and secondary education, higher education is certainly not immune from unsuccessful fads. Best (2006) recounted some of the recent trends that have spread through most colleges and universities, insisting that virtually all of them were not only short-lived, but that none appeared to make a significant impact on the quality of education. As a result, the available inventory of widely accepted, dependable, enduring principles of good practice is a somewhat limited one.

\section{The Seven Principles}

Chickering and Gamson's (1987) Seven Principles for Good Practice in Undergraduate Education appear to provide a good set of ideas and might serve as a framework for faculty evaluations, because they describe elements of an effective instructor's teaching style. They qualify more as a set of all-around benchmarks rather than a specific teaching model. They are sufficiently versatile to remain above the parochialism of specific theories, and they are based on a substantial body of the available literature available at the time they were devised, and have subsequently been bolstered by an additional body of literature that emerged throughout the 1990s.

Moreover, the seven principles are often cited in the leading books in the field. For example, in his work on effective teaching evaluations, Centra's (1993) fundamental differentiation between passive and active teaching methods relies upon some of those seven principles to illustrate the general principle of learner-centered pedagogy. 
Likewise, in their examination of the factors that contribute to the success of awardwinning faculty, Baiocco and DeWaters (1998) repeatedly pointed out the connections between successful classroom behaviors and the practices advocated by the Seven Principles. In the same vein, Gates et al. (2002) specifically cited Chickering and Gamson's (1991) work to illustrate useful process measurements that can be convincingly linked to desirable student outcomes.

The Seven Principles of Good Practice in Undergraduate Education (Chickering $\&$ Gamson, 1987) are indeed more than a passing fad in the higher education literature. For example, in their extensive review of educational quality evaluation literature, Gates et al. (2002) cited the Seven Principles as useful guidelines for developing process measurements that can identify practices that generate positive student outcomes; thus, becoming concrete indicators of good teaching quality. Furthermore, they have been the subject of a number of studies that tend to support their validity as quality benchmarks.

\section{History of the Seven Principles}

The idea for the Seven Principles was born in 1985 during a board meeting of the American Association for Higher Education (AAHE), in which the perceived need for a statement of principles that would guide the improvement of undergraduate education was discussed. The outcome of that extended dialogue would be eventually articulated as a set of universal standards of good practices for college instructors, which would be summarized into a set of seven guidelines. Although the final document was authored by Chickering and Gamson, the Seven Principles for Good Practice in Undergraduate Education reflect the collective wisdom of a group of the leading researchers in higher education during the mid-1980s, who gathered at Wingspread conference center at 
Racine, Wisconsin, in July 1986, and after dispersing again to their respective institutions continued the dialogue across the nation (Chickering \& Gamson, 1999).

The goal for the Wingspread group was to develop a consensus on how to improve undergraduate education in American colleges that could ultimately be encapsulated in a list of no more than nine concrete teaching practices, which in turn could be reproduced on a single page and be easily adopted by teaching faculty. Both Chickering and Gamson insisted on a limited number of key principles, based on the existing cognitive research literature that posited that most individuals have the ability to remember between five and nine single concepts (Gamson, 1991). Thus, the participants in this project endeavored to distill the collective wisdom of the 1980s teaching and learning research literature, into a concise set of core values that could be applied in any college classroom.

The social forces that appeared to be driving the Wingspread group's efforts were primarily the changing face of the student population, and the pressures for more accountability in higher education. Among the authors cited by Chickering and Gamson, one who also became a contributing member of the Wingspread group, was Bowen (1977). Along with other collaborators, Bowen published an extensive report under the auspices of the Sloan and Carnegie foundations. That work amounted to a metanalysis of the then-existing literature about the past, present and future of higher education, listing over 500 references. Analyzing what seemed to work and what did not work, and rationalizing the need for radical changes in the higher education system, Bowen could be considered one of the forerunners of the educational reform movement of the 1980s. 
Anticipating the shift from traditional college student to nontraditional ones in growing numbers, Bowen (1977) argued that the entire higher education system would need to change to accommodate this new breed of students, envisioning radical changes in the methods of instruction among other things. An important notion that Bowen introduced in his work was the need to discard the reliance on input measurements, such as the resources utilized, in favor of measuring outcomes, such as learning, as a more satisfactory way of responding to the growing demands for accountability. This would become an integral part of the theory of student involvement that emerged during the 1980s, after Bowen's participation in the National Institute of Education's (NIE) Study Group on the Conditions of Excellence in American Higher Education.

Another participant in the Wingspread group was Cross (1986), whose work was also cited by Chickering and Gamson, and who was a strong advocate of the use of the Personalized System of Instruction (PSI) in higher education. The merits of PSI are a recurring theme in the higher education literature, as evidenced by nearly 300 articles spanning 4 decades in the ERIC database; moreover, PSI has often been cited as a natural alternative to the traditional lecture method of instruction, and as an answer to the rising challenge of student diversity. Thus, the underlying principles that lend support to PSI correspond with the imperative of the seventh principle; to respect diverse talents and ways of learning. Presumably, when confronted with a diverse student population with both different levels of ability and learning preferences, a rational solution would arguably be to adapt the instructional methods to the needs of the students, which is why the theory at the core of the PSI model presented a good basis for some of the discussions of the Wingspread group. 
Gamson's association with the NIE's Study Group, in which two other key members of the Wingspread group served, would also prove to be a very influential factor in the formulation of the Seven Principles. According to Adelman and Reuben (1984), the NIE assembled the Study Group within months of the publication of the widely circulated document, $A$ Nation at Risk (U.S. Dept. of Education, 1983). The Study group can probably be considered a precursor to the Wingspread group, with its farreaching mission of reviewing the body of both research literature and common practices, and its ultimate goal of making recommendations to generally improve higher education curriculum and instruction throughout the U. S.

To carry out that enormous task, the Study group also relied on the work compiled by other groups or organizations. One such group was the National Commission of Excellence in Education, of $A$ Nation at Risk notoriety. The National Commission was originally charged with examining educational programs from an array of institutions across the nation, and identifying and describing the ones deemed successful in meeting the goals of higher education, with the emphasis in the quality of learning and teaching. This wide-ranging study examined and correlated among other things, objectives and underlying theories of each program, measurements of student achievement, and the characteristics of the students (Adelman \& Reuben, 1984). In turn, the National Commission presented a compilation of the synthesized data and some updated program descriptions to the Study Group on the Conditions of Excellence in American Higher Education.

The final report of the Study Group was entitled, Involvement in Learning: Realizing the Potential of American Higher Education (1984). Consequently, the concept 
of involvement in learning would be expanded upon in short order, and used as the label for an emerging paradigm that would eventually serve as the foundation for most of the Seven Principles. In essence, the Study Group's conclusion was that the American higher education establishment needed to make student learning its highest priority, and accordingly made a number of recommendations to that end. Nevertheless, the report was intensely critical of the lack of outcome measurements that would more accurately gauge the quality of education, and stressed the need for more effective teaching and learning grounded on research findings, at the same time pointing out that there was a body of research literature that was being largely ignored.

Thus, the recommendations issued by the Study Group were presumably based on research findings. The central concepts of that new theory became involving the students in their learning, conveying higher expectations to the students, and the inclusion of assessments that would allow feedback on performance. This provided a framework for the specific recommendations that would later be synthesized into the Seven Principles. For example, student involvement was found to be closely associated with the time and effort that students devoted to their learning, which would eventually be summarized from a practical standpoint as emphasizing time on task.

Perhaps the most influential participant in the NIE's Study Group, who later participated in the Wingspread group, and whose work is referenced in the original Seven Principles document, is Alexander Astin, whose contributions to the higher education literature span close to 50 years. The foundation for his notions on the factors that play a key role in academic achievement was his extensive research into the attitudes and behaviors of college students, dating back to the 1960s (Astin, 1965, 1968, 1971), and 
crystallizing into the theory of Student Involvement after his longitudinal study of college dropouts (Astin, 1975).

At the time Astin joined Gamson and Bowen in the Study Group, he was already working on his theory of Student Involvement. More specifically, Astin shared part of his still unfinished book with the other Study group members, and some of this material would be incorporated in the Study Group's final report (Astin, 1985). In chapter 6 of his book Astin offered a teaching paradigm that would be responsive to the needs of a more diverse student population, based on his own studies spanning two decades, and an extensive review of the existing literature; thus, making a case for four principles of good teaching practices.

Those tenets would later become four of the original seven principles promoted by Chickering and Gamson: (a) encouraging contact between students and faculty, (b) giving prompt feedback to students, (c) emphasizing time on task, and (d) respecting diverse talents and ways of learning (Chickering \& Gamson, 1987). In essence, there are only minor differences between Astin's original prose and the wording that Chickering and Gamson used to describe those four principles. Thus, the backbone of the seven principles appears to be the theory of Student Involvement, as explained in chapter 6 of Astin's (1985) work. Nevertheless, it also becomes apparent that the Seven Principles were more than anything, the product of the symbiotic relationship of some of the most prominent researchers of the $1980 \mathrm{~s}$.

\section{General Predictive Validity}

One of the most extensive studies on the impact of the Seven Principles was the one conducted by Cruce, Wolniak, Seifert, and Pascarella (2006). The data for their study 
covered students in eighteen four-year institutions and five two-year colleges $(n=2,474)$. This sample was meant to approximate a cross-section of the national student population. The data were obtained from the National Study of Student Learning (NSSL), a longitudinal study of the factors influencing learning and student development. It included an instrument to measure orientations to learning, and a standardized test developed by ACT to measure academic skills, and also utilized the College Student Experiences Questionnaire data.

The authors then developed 19 scales that were consistent with Chickering and Gamson's (1987) Seven Principles, to measure the impact of the Seven Principles on various dimensions of first-year students' development. The results suggest that the implementation of those Seven Principles in the classroom significantly contributes to students' learning and personal growth, irrespective of their academic preparation.

Another extensive study was conducted by Carine, Kuh, and Klein (2006) at 14 colleges and universities that examined the influence of various measures of self-reported student engagement $(n=1,058)$. Three of those measures were consistent with three of Chickering and Gamson's (1987) Seven Principles: (a) level of academic challenge, (b) active and collaborative learning, and (c) student-faculty interaction. In turn these indicators were correlated with students' GPA and GRE scores. Although the authors' results indicated a modest positive correlation between those self-reported measures of student engagement and academic achievement, the three indicators linked with the Seven Principles still tend to corroborate the positive findings of other researchers as predictors of student achievement. 
In an earlier but also extensive study of students from several institutions $(n=911)$, Kuh, Pace, and Vesper (1997) examined the psychometric properties as process indicators of student performance, of some of the principles espoused by Chickering and Gamson (1987), by selecting various items from the College Student Experiences Questionnaire that were aligned with the processes described in three of the Seven Principles. Those three were: (a) faculty-student contact, (b) cooperation among students, and (c) active learning. The results indicated that the best predictor of self-perceived academic gains for both men and women was engagement in active learning methods, and the second best cooperative learning, virtually irrespective of other student characteristics.

\section{Latent Combined Effects}

Beyond individual outcomes, there are several studies that suggest that the positive effects of the Seven Principles tend to reinforce each other. Another interesting finding yielded by the Cruce et al. (2006) study indicated above was that the composite estimate of the effects of the three scales representing three of the Seven Principles was larger that the sum of the effects of the individual scales. This suggests that integrating some of those practices will yield better results than implementing them individually in isolation.

In a similar vein, Kuh et al. (1997) also maintained that the evidence in their study suggests that when instructors combine two or more of those principles of good practice in a single task that the students can carry out, the result is an increase in self-reported achievement, greater than the sum yielded through the implementation of the individual principles used in isolation. This is consistent with Chickering and Gamson's (1987) 
stance about the synergistic effects of the Seven Principles when utilized together as a system instead of in isolation.

\section{Normative Support for the Seven Principles}

Another important area of research with regards to the validity of Chickering and Gamson's (1987) Seven Principles has been to ascertain if there is a normative structure in place that generally supports those behaviors among both faculty and students. Surmising that recommendations for best teaching practices are more likely to be implemented by faculty members when they conform to the standards of the group, Braxton, Eimers and Bayer (1996) reviewed the literature on improving college teaching and selected six common recommendations. Among those selected, there were two that corresponded directly with Chickering and Gamson's (1987) recommendations: (a) encouragement of faculty and student contact, and (b) feedback on student performance.

The researchers then utilized the responses from 253 faculty members from several institutions, who were asked to rate the appropriateness of the 126 teaching behaviors listed in the College Teaching Behaviors Inventory, which were indexed to the six recommendations. It is important to note that providing feedback to students was the only recommendation that enjoyed significant support from faculty members at all institutions, regardless of their discipline.

In a similar subsequent study, Eimers, Braxton, and Bayer (1998) examined faculty's normative support at liberal arts and community colleges for the same six recommendations. The results once more mirrored those obtained in the previous study conducted at large research universities, with providing prompt feedback to students again receiving wide support from faculty members. The implication of that finding is 
that this teaching practice may be the only one that is implemented nearly universally by faculty members, out of Chickering and Gamson's (1987) Seven Principles.

Conversely, Caboni, Mundy and Duesterhaus (2002) examined the normative support on the part of students, specifically for Chickering and Gamson's (1987) Seven Principles. The researchers found that three of the principles are supported by a significant portion of the student body: (a) student-faculty contact, (b) cooperation among students, and (c) high expectations from faculty. However, the results varied by race, gender, and class standing; thus, falling short of receiving universal acceptance. Although this study was limited to a single institution, it suggests that the implementation of at least three out of the seven principles may be embraced as part of the social contract between instructor and students, by a significant number of students.

These findings from normative studies suggest that the implementation by faculty members of at least three of the Seven Principles should be perceived favorably by a significant number of students, and be ultimately associated with practices that promote learning. Thus, measuring the presence of processes that are aligned with the Seven Principles as determined by the students, may result in more objective indicators of teaching quality.

\section{A Description of the Seven Principles}

The fundamental goal of Seven Principles is to motivate students to learn, and to involve them as active participants in their learning. College teaching methods can be conceptualized on a scale that ranges from the most passive to all the other approaches that incorporate more or less active learning techniques. Essentially, learning modes can be described in terms of who is the performer of the actions in the teaching-learning 
process. In passive learning the teacher is very active, while the students passively sit listening or taking notes at the most. In active learning, the students become actively involved in their own learning process, while the instructor adopts the more passive role of an adviser. Thus, in a continuum from passive to active we have at one end the traditional lecture, while the other extreme would be represented by independent learning (Centra, 1993).

Within that continuum, some of the active learning methods that increase students' involvement in their own learning include simple class discussions and team projects (Chickering \& Gamson, 1987). More structured activities include the problemsolving case method developed at Harvard. On the other hand, active learning methods are not necessarily limited to group learning activities, but may also comprise individualized learning methods, such as PSI, and computer-based instruction (Sorcinelli, 1991). Following is a short description of some of their support in the literature.

Contact between student and faculty. Chickering and Gamson (1987) maintained that faculty members should become a resource for students, in and outside of the classroom. This specific principle, which emphasizes the interaction between instructor and student, is grounded on the literature of the 1980s, but it still receives support in the more recent research literature.

Kuh and $\mathrm{Hu}$ (2001) conducted an extensive longitudinal study $(n=5,409)$, specifically to investigate the effects of student-faculty interaction, drawing data from a stratified sample of the College Student Experiences Questionnaire spanning seven years. The results generally indicate positive correlations between student-faculty interaction and self-reported net gains, including satisfaction. The data also suggest that formal 
interaction outside the classroom, such as visits during office hours to discuss course work, or ask for advice on improving writing skill, is an effective form of interaction. On the other hand, informal contact, such as going for a cup of coffee with the faculty member, or visiting to discuss personal problems, had a much more limited impact on student satisfaction and gains.

Another interesting finding in this study is the evidence that suggests that such interactions may help increase the amount of effort that students devote to other academic pursuits, which will in turn also influence their perceptions of academic achievement. These results are consistent with other studies that suggest that student-faculty interaction has a positive effect on student satisfaction and perceptions of learning.

In another large study $(n=1,258)$ of perceptions of classroom climate by gender in engineering courses conducted by Colbeck, Cabrera, and Terenzini (2000), the researchers also measured the relationship between students' perceptions of instructor classroom behaviors and students' self-perceptions of personal gains. The findings indicate that regardless of gender and student background, frequent student-instructor interactions significantly contributed to student perceptions of increased confidence in their abilities, and motivation to complete the course.

In another related study, Briane, Wong and Wiest (1999) compared students' midterm grades with their perceptions of instructor immediacy behaviors in the classroom, concluding that the frequency of reported positive behaviors such as the use of humor and smiles were significant predictors of their grades. In addition, a number of other studies have also linked perceptions of instructor immediacy to student perceptions of growth (see; Cruce, Wolniak, Seifert, \& Pascarella, 2006; Graunke, Woosley, \& Sherry, 2005; 
Jin, 2005; Swan, Shea, Fredericksen, Pickett, Pelz, \& Maher, 2000; Koljatic, \& Kuh, 2001).

In conclusion, the body of literature suggests that there is a strong link between perceptions of the immediacy of the instructor, and perceptions of personal and academic gains by the students. Thus, asking students to rate their level of satisfaction with the interaction that they have had with the instructor, could also be an effective form of measuring perceived student gains, as an indicator of instructional quality.

Reciprocity and cooperation among students. Although cooperative learning is often equated with collaborative learning, there are some fundamental differences. Essentially, cooperative learning is more structured, with the instructor assigning specific roles to team members, actively observing the participants, and often intervening. On the other hand, with collaborative learning the instructor tends to stand on the sidelines once the task is handed out, assuming that the students are mature learners who have the social skills to interact effectively, and complete the task with minimum assistance (Beachler \& Gyer-Culver, 1998). The literature suggests that collaborative learning is the most common of these two methods (Arendale, 2005).

There is ample evidence to suggest that collaborative learning has positive effects on students, on both cognitive and affective dimensions, whether used by itself or in combination with other teaching methods. In their study, referenced above, Colbeck, Cabrera and Terenzini (2000) also investigated the effects of teaching methods by gender, and found that both male and female students reported significant personal gains that were attributable to collaborative work with peers. In a similar study, Kuh, Pace, and Vesper (1997) identified good teaching practices as useful process indicators of student 
achievement. When they investigated the effects of some of the Seven Principles by gender they found that cooperation among students was the second-best predictor of selfreported gains in academic achievement, for both men and women.

In a slightly different study, Krank and Moon (2001) measured the effects of cooperative learning and mastery learning, used separately and combined. The results indicated that both methods achieved increases in self-reported personal gains, and academic achievement as evidenced by pre-tests and post-tests. However, the affective gains were slightly higher with collaborative learning, and the cognitive gains were slightly higher with mastery learning.

More to the point, most of those findings suggest that incorporating collaborative learning activities in a course promotes student learning. Thus, in the absence of pretesting and post-testing to obtain a true measure of student academic gains, measuring the students' perceptions of the opportunities for collaborative learning that have been facilitated by the instructor may result in a reasonable indicator of instructional quality.

Active learning. As indicated above, Centra (1993) explained active learning as any methods employed by the instructors that will engage the students in concrete actions, beyond the mere listening and note-taking required by lectures. Thus, with active learning, the instructor's efforts shift from lecturing to students who remain passive receivers of knowledge, to organizing activities that will compel the students to become active participants in the learning process. Moreover, Centra cites Chickering and Gamson's (1987) Seven Principles as prime examples of methods that foster active learning, and are eminently suitable models of good teaching practices. Centra's notions have had a lasting impact on the scholarship of college teaching and learning; thus, it is 
virtually axiomatic in the literature that the best teaching practices include engaging students in active forms of learning.

Among the studies that have investigated the validity of active learning techniques, the Kuh, Pace and Vesper's (1997) study cited above is probably one of the most of the most often cited in the literature. The researchers investigated the effectiveness of several good teaching practices that were aligned with some of those advocated by Chickering and Gamson (1987), as process indicators of students' perceptions of personal and academic growth. The results suggested that the best predictor of student gains was the implementation of active learning methods, for both men and women, regardless of academic and personal background.

In a different type of study, the findings of Braxton, Milem, and Sullivan (2000) suggest that the implementation of active learning methods in the classroom may play a key role in the social integration and retention of first-year students. The active learning classroom behaviors were represented by four measures that included class discussions and group work. Those two indicators are also components of the Seven Principles. Based on the results, the researchers contend that faculty appear to have the greatest influence on students' decisions to remain in college, largely through their choice of teaching approaches.

As suggested by those findings, the incorporation of active learning techniques tends to have positive effects on students' perceptions of learning, as well as contributing to persistence in college. Thus, another good indicator of instructional quality may be the extent to which the students report engagement in learning activities that have been 
facilitated by the instructor, which go beyond reading the textbook and listening to lectures.

Prompt feedback. In the final report of the Study Group on the Conditions of Excellence in American Education (U. S. Department of Education, 1984), the third condition of teaching excellence is to conduct frequent assessments of student learning, with the corresponding feedback, as a means of promoting student involvement in their own learning. Moreover, the Study Group emphasizes the connection between feedback and instructor expectations, by affirming that students are more likely to take action after receiving performance feedback, when high expectations have been clearly conveyed by the instructor. Therefore, the benefits of frequent assessments and the subsequent feedback to the students are recurring themes in the literature, although not always together as part of the same study, but instead often combined with other factors. Nevertheless, there appears to be sufficient evidence to support the efficacy of prompt feedback as a learning tool.

As indicated above, Colbeck, Cabrera, and Terenzini (2000) studied the effect of various teaching practices, on the self-reported personal gains of male and female engineering students enrolled in seven universities in the Northeast. The results indicated that the instructor's behaviors in the classroom have more influence on the selfperceptions of both male and female students than their personal characteristics and academic background. The study was also correlated with learning outcomes. Those results suggested that frequent student-faculty interaction, of the kind that also included detailed feedback, significantly contributed to boosting student confidence, motivation, and persistence. 
In Rucker and Thompson's (2003) similar, but somewhat more limited study at a single university ( $n=104)$, a majority of the students indicated that specific feedback was important to their learning. Moreover, the results indicated that the promptness of the feedback correlates with the students' perceptions of its usefulness. Finally, as part of their interpretation of the data, the authors posited that feedback is an inviolable component of the implicit contract between faculty and student, any time that the instructor gives an assignment.

What is more, other studies have noted that the immediacy of the feedback also appears to have an effect on learning. Brosvic and Epstein (2007) conducted a study that compared the effects of providing immediate feedback of the results after five multiple choice exams, with a delayed feedback of the accuracy of each answer on the test, with students enrolled in an introductory psychology course. The study included a longitudinal component, in which the participants $(n=467)$ were given retention tests at 3 -month intervals over the year after the course ended. The results indicate that the long-term retention of the materials covered in the tests increased significantly for those students who received immediate feedback.

Thus, the literature on the effects of instructor feedback suggests that this is an important learning tool across the disciplines, and in addition is fairly independent of student characteristics. Furthermore, the timeliness of the feedback also appears to be an important indicator of teaching effectiveness, because it has a significant effect upon students' perceptions of learning. Thus, student perceptions of the extent of the feedback offered by the instructor, combined with perceptions of the timeliness of the feedback, should also be positive indicators of instructional quality. 
Time on task. The notion of time-on-task is at the core of the theory of student involvement, advocated by the Study Group on the Conditions of Excellence in American Higher Education (U. S. Department of Education, 1984), and as indicated above, also reaffirmed by Astin, (1985). Those two works proved to be influential in the development of the Seven Principles. The principle of time-on-task is actually a simple one, defined by Chickering and Gamson (1987) in terms of a very simple formula: time plus energy equals learning. Thus, the time that a student spends engaged in all learning activities can be considered roughly proportional to the learning that takes place.

In a study of children in reading classes, Gettinger (1984) found that the time spent in learning was proportional to the retention level of the participants, based on standardized tests. The researchers first measured the number of trials that several representative samples from the school district's population required to master a task with $100 \%$ accuracy, by exposing the children to repeated taped unit lessons and retesting after each session, to establish time needed and to arrive at a ratio for each sample. They then selected random samples of children with similar characteristics, and measured achievement after exposure to a fewer number of lesson. In every case, the results indicated that those samples who were exposed to a fewer number of lessons than the control group underachieved roughly in proportion to the reduction in the number of lessons received.

Nevertheless, the research literature on the effect of time on task on college student performance is sparse. This is perhaps in part because the concept also appears to be included under the construct of student engagement. Furthermore, it is inconclusive, because there is little or no direct evidence for college students of the connection between 
the amount of time spent in learning and achievement. For example, Spaulding and Dwyer (2001) investigated the relationship between various levels of job aids. Although all students who were provided with the additional materials did better on the assigned task than the control group with no aids, the results on the relationship between time on task and types of aids utilized were insignificant.

In a more specific study, Laird, Shoup, Kuh, and Schwarz (2008) investigated the relationship between self-reported students' learning efforts and achievement. However, the authors could only establish a weak relationship between such self-reported learning efforts and grades. In a similar vein, Nonis and Hudson (2006) conducted a study of the effects of time spent studying outside of class and other tasks related to academic performance. Not only did the authors find little correlation between the time the students reported studying and academic performance, but rather, the data suggested that student motivation and behaviors had a stronger influence on academic performance than any other factors.

Moreover, Carini, Kuh, and Klein (2006) conducted a relatively large study ( $n=1058)$ at 14 institutions of higher education , which suggested that the relationship between academic achievement and engagement in learning tasks is a tenuous one, observing that student engagement is only one of the many factors that influence academic achievement. Furthermore, the authors found significant variances among groups of students with different characteristics that they were unable to explain. Rather than speculate further upon the findings, the authors suggested that the variances they found are a function of other factors that have yet to be explained. 
In summary, the time on task literature at college level does not abound, and the somewhat limited findings about the effects of time on task on academic performance are ambivalent. Thus, the concept may or may not turn out to be useful in determining student satisfaction, based on the lack of reliable empirical data.

Communicating high expectations. According to some of the literature, the communication of high expectations by the instructor will typically stimulate a significant number of students to attain higher levels of achievement. Although this seems to be an intuitive notion about human nature- ask for more and you shall receive more, there is sufficient empirical evidence to support the belief that this practice has some positive effects on students' perceptions of personal and academic growth.

The principle of communicating high expectations is grounded upon Rosenthal and Jacobson's (1968) theory of teacher-expectancy effects, in which they postulated that teachers' beliefs of students' abilities and ensuing expectations of performance have an effect upon individual students' academic performance. The authors conducted a study in which children were pre-tested, after which a randomly selected group was fallaciously represented to their teachers as high-achievers. The data indicated that the group of children whom their teachers were wrongly led to believe were high achievers based on the results of the pre-test, generally realized higher gains on the post-test at the end of the semester than the entire sample.

While this theory generated a great deal of interest throughout the following two decades, it must be kept in mind that in some subsequent studies, the findings turned out to be inconclusive (see Jose \& Cody, 1971; Schwarz \& Cook, 1972; Goldenberg, 1992). Thus, in spite of its popularity in both the academic and popular presses, Rosenthal and 
Jacobson's (1968) work spawned considerable controversy. One notable critic was Robert Thorndike (1968), who disapproved of Rosenthal and Jacobson's choice of methodology and publicly questioned the validity of the findings. Nevertheless, the effects of the selffulfilling prophesy or the Pygmalion effect, as it also came to be known, provided the starting point for the study of the effects of teacher expectations on students, which would eventually also encompass the higher education classroom, although from an entirely different perspective.

An important distinction between the teacher expectation effects research efforts devoted to school children, and those conducted among college students is that with the latter, the focus has been on measuring perceived rather than actual gains. Thus, one of the leading instruments in acquiring national data about student perceptions and satisfaction for about the last two decades has been National Survey of Student Engagement (NSSE), which contains items that are closely linked to the values articulated in Chickering and Gamson's (1987) Seven Principles.

In a relatively large study $(n=2,012)$, Ryan (2005) used the Seven Principles as the framework for a study of first-year and senior students at a large research university, by extracting data from the National Survey of Student Engagement (NSSE), and drawing parallels between a number of the self-reported class activities on the NSSE instrument and several of the seven principles. Although limited to a single institution, the results of that study suggest that communicating high expectations to the students, along with providing prompt feedback, are the most influential teaching practices when it comes to self-reported student achievement and satisfaction. 
In a similar vein, Belcheir (2001) used the NSSE data from Boise State University to establish what factors were the best predictors of student satisfaction and perceptions of growth. One of the most significant findings was a strong correlation of self-reported personal growth with students who reported that they worked harder than they thought they could to meet an instructor's expectations. This was largely true of both freshmen and seniors; thus, communicating high expectations may not only be a powerful motivator, but may be generalized to the entire undergraduate student population.

Kuh, Laird, and Umbach (2004) instead designed their own survey instrument to measure the frequency and type of activities that faculty used to engage students, patterned after some of the questions in the NSSE questionnaire. The researchers then compared the data reported by faculty with the self-reported data from the students, sideby-side. An interesting finding was that at institutions where a significant number of faculty members placed emphasis on communicating high expectations to the students, the students' self-reported gains in general education tended to be higher than at other institutions. Thus, the researchers rationalized that high expectations tend to influence student performance when they are clearly communicated to the students.

Although the literature on the effects of teacher expectations on the students remains somewhat ambivalent after forty years, this does not appear to be true for higher education, where it is the perceptions of students that are primarily measured. The literature suggests that high but attainable academic expectations from faculty have a positive effect on college students' perceptions of gains. Thus, the clear articulation of high expectations by faculty members may be construed as an indicator of effective teaching, in terms of students' perceptions. 
Respecting diverse talents and ways of learning. There are many reasons why Chickering and Gamson's (1987) seventh and final principle may be related to students' perceived levels of learning and growth. First, there is an extensive body of literature that makes a case for diversity of learning styles, and students as individuals (Brown, 1979; Dunn, 2000; Dunn \& Dunn, 1979, Dunn \& Dunn, 1978; Dunn, Griggs, Olson, Gorman, \& Beasley,1995; Hunter, 1980; Sullivan, 1998). Thus, it follows that best practice dictates that instructors try to accommodate different types of learners, by using a variety of teaching methods. Outside of that, there's solid evidence that suggests that using a variety of teaching methods will also tend to strengthen the effects of all those other good practices (Cruce, Wolniak, Seifert, \& Pascarella, 2006), resulting in a synergistic effect that will boost student gains beyond the sum of the effects of the individual methods employed.

A good example of this was a study cited above conducted by Krank and Moon (2001), in which they measured the effects of mastery learning and cooperative learning techniques on undergraduate students' academic achievement and self-concepts. The two techniques were used separately in two different courses, and then combined in a single course. The composite results indicated that the two techniques combined yielded a greater combined effect on both achievement and self-concept, than when either method was used alone. Although limited by the sample size for the three treatment groups ( $n=104)$, these findings tend to support what many theorists claim, which is that using a variety of teaching methods will increase learning.

The key in accommodating different learning styles is to provide an array of learning opportunities. However, there may be some overlap between this principle and 
one or more of the others previously enumerated. For example, Chickering and Ehrmann (1996) used collaborative learning as an example of one of the strategies that will promote learning for students with different cognitive styles. Thus, it is only to be expected that a degree of correlation may be present between this principle and some of the other principles that may promote analogous methods.

\section{The Role of the Seven Principles in Online Courses}

The unprecedented growth of distance education, concurrent with the growth of the World Wide Web, transformed many of the processes that take place in the classroom. This presented researchers with new challenges in assessing and understanding the new methodologies used in online teaching. While the basic processes and the actors remained the same, the procedures for instructional delivery and interaction of the participants changed radically. This is because Internet-based courses are for the most part asynchronous, and because the role of the instructor is now computer-mediated as opposed to face-to-face. What follows is a summary of the research into those differences.

\section{Differences and Similarities}

In a relatively large study of online students that correlated student satisfaction with learning outcomes, Eom, Ketcherside, Lee, Rodgers, \& Starrett (2004) conjectured that the role of the instructor is as critical to both perceived satisfaction and learning in online courses, as it is in traditional classroom courses. Nevertheless, although there are some fundamental principles that apply to any teaching situation, the online medium requires different processes as well as more careful planning, because of the distance between instructor and learner. Conceição (2007) maintains that the role of the effective 
online instructor must include a number of specific strategies that complement the online medium, but would not necessarily be used in the traditional classroom. For example, rather than a lecturer, Conceição emphasizes that the online instructor often becomes a facilitator in the sidelines who tries to engage the students in the learning process.

Likewise, Conceição envisions the instructor as a catalyst who instigates threaded online discussions and often becomes a participant in those. Therefore, the process indicators of effectiveness that would be used for the traditional face-to-face classroom need to be reconsidered and adapted to the online medium.

In a study of experienced instructors in both traditional classroom and online teaching, Smith, Ferguson, and Caris (2002) categorized their perceptions of the major differences between the two modes of instruction. The most frequently cited differentiating characteristic was the constraints of communicating with the students online. Some of the issues cited were the lack of visual cues in the communication process that can easily lead to misunderstandings, and the challenge of creating an "online presence" as a surrogate for the personal interaction in a traditional classroom. In Smith and colleagues' (2002) study the second major category of instructor responses centered around the need for meticulous planning and explicitness on the part of the online instructor, since online courses are conducted in an asynchronous mode, which does not afford the opportunities for immediate clarification that exist in the traditional classroom, where all participants have real-time face-to-face contact.

\section{The Need for Interaction}

Probably the most important point that emerges in the distance education literature is the need for frequent interaction between students and instructor, which 
although relatively straightforward in a traditional face-to-face classroom, becomes more challenging in the asynchronous electronic medium, where instructor and student are separated by both distance and time. Jiang and Ting (1999) surveyed State University of New York (SUNY) students participating in 78 different online courses about their perceptions of learning, according to the learning activities in the course they were taking. According to the students' responses, frequent interaction with the instructor was considered the most important factor for success in online courses, with participation in online discussions as the second most important factor being equated with successful learning. Likewise, Phipps and Merisotis (2000) identified facilitation of student interaction with instructor and other students, as the most important benchmark in assessing the quality of online courses.

In a metanalysis of the online literature Yiping (2006) reported that interaction was the most robust predictor of student achievement, with student-instructor interaction specifically accounting for the largest variance. In another metanalysis of the literature on online course effectiveness, Yong (2006) concluded that interaction is the key predictor of educational quality in online courses, stressing that student-instructor interaction is the key factor in perceived course effectiveness. Moreover, the author suggested that a vital role of the online instructor is to remove the "distance" from distance education, through an extensive and active involvement in the course, rather than just remain a silent observer on the sidelines.

Thus, we could explain the "distance" in distance education as: (a) the absence of face-to-face interaction between instructor and learner, and (b) the asynchronous or timedelayed nature of communication in distance education courses. Although those two 
shortcomings have been present since the era of correspondence courses, they became burning issues with the unprecedented growth of Internet-based courses, and the ensuing controversy over the quality of online education, as opposed to traditional courses that were taught face-to-face.

This debate generated an entire body of literature, which became known as the "no significant difference" phenomenon, a term originally coined by Russell (1999) in an annotated bibliography of 355 studies between 1928 and 1998, with findings that suggested no significant difference between the effectiveness of distance education courses and traditional face-to-face courses. However, Russell's postulation generated some controversy, particularly because most of those studies cited had drawbacks that included small sample sizes (less than 40 participants) and poor response rates (Lei, Yan, \& Zhao, 2005).

\section{The Adaptation of the Seven Principles}

The apparent shortcomings of the new electronic medium were addressed by Chickering and Ehrmann (1996) in their adaptation of Chickering and Gamson's (1987) original Seven Principles. The authors proposed that the new technologies ushered in by the World Wide Web have become innovative tools to improve instructional quality. Moreover, this article mirrored the descriptive approach of the original Seven Principles by offering practical advice for the appropriate use of technology to implement the processes outlined in the original document in the online classroom. Eventually, the principles embodied by this document would become the foundation for the assessment of online courses and entire online programs. 
At the time that Chickering and Ehrmann collaborated in their adaptation of the Seven Principles, Ehrmann was working in partnership with Gilbert on the development of the Teaching, Learning, and Technology Group (TLT Group). According to Ehrmann (1995), the initiative was born as a collaborative effort between the Western Interstate Commission on Higher Education and various universities, and its primary mission would become the development of methods and procedures to evaluate and improve distance education programs. Initially, the TLT Group operated under the sponsorship of the American Association for Higher Education, becoming an independent organization in 1998 (Miller, 2005). Today the TLT Group has 150 member colleges and universities. Under Ehrmann's leadership, the organization has become the repository of an extensive collection of data about the use of the Seven Principles, available to member institutions.

Four years after Chickering and Ehrmann (1996) published their adaptation of the Seven Principles, Graham, Cagiltay, Craner, Lim and Duffy (2000) endeavored to operationalize them as process indicators of instructional quality in online courses. To do this they evaluated the instructional quality of four online courses, largely from the students' perspective. The authors observed and classified the interactions among students, and between student and instructor, correlating all their observations with the processes embodied in the Seven Principles. The result of that was a critique of how well the Seven Principles had been implemented in those courses, along with recommendations for improvement, by incorporating more of the processes that the principles suggest. The author's work, later published in a widely-read online journal (Graham et al., 2001), likely focused considerable attention on the Seven Principles as viable process indicators of quality in online courses. 
As indicated above, Phipps and Merisotis (2000) conducted a study sponsored by the National Education Association (NEA) in which they reviewed the best teaching practices literature to identify 45 quality benchmarks for online courses, and then surveyed students, faculty, and administrators at a number of colleges and universities, in order to rate their relative importance. The result of this was a list of 24 benchmarks of institutional and instructional program quality, five of which correlate with Chickering and Gamson's (1987) original Seven Principles, and with Chickering and Ehrmann's (1996) adaptation of the Seven Principles. This NEA-sponsored study was widely cited in the literature.

In a more recent study, Bangert (2006) tested a new evaluation instrument in both fully online and partially online courses, in which the items were derived from Chicketing and Gamson's (1987) original Seven Principles, and from Chickering and Ehrmann's (1996) subsequent adaptation. Nevertheless, Bangert did not separate the responses by type of course for the analysis; thus, any latent effects as the result of the students' face-to-face interactions with the instructors may not be identified. This may be a significant concern because the character of the interactions in both settings are radically different, as evidenced by the literature. To further complicate matters, those students taking the hybrid courses comprised a substantial $42 \%$ of all respondents, and the proportion of face-to-face class time vs. online time remains unknown.

The second issue at hand in Bangert's study has to do with the nature and the wording of some of the questions. For example, there are a few questions that appear to be beyond the instructor's control, such as whether questions about the WebCT online course platform were responded to promptly. To all intents and purposes, such questions 
have nothing to do with teaching effectiveness, because in most higher education settings the students would typically contact support services directly for assistance. Likewise, the wording of some o those questions could pose a challenge to the students. For example, how students may interpret, "an efficient learning environment," is open to speculation. Therefore, this study will also seek to clarify all those ambiguities.

\section{Validity Issues}

The validity of student evaluations of instruction has long been a controversial issue in the literature. As Greenwald (1997) asserted, after the 1970s decade of intensive research and ensuing controversy over the findings, there followed a period of general contentment with the validity of student ratings. Nevertheless, the controversy reemerged at the end of the 1990s, only to rekindle some of those erstwhile differences of opinion, with some prominent researchers in the field, such as Ory (2001), suggesting that there was more research to be done before all the questions were settled.

\section{Evidence of Validity}

As several researchers (Cashin \& Downey, 1992; Marsh \& Roche, 1997; Hobson $\&$ Talbot, 2001) have aptly observed, the measurement of effective teaching is not confined to a specific set of commonly agreed-upon indicators; rather, it has been associated with a relatively wide number of factors, thereby resulting in a somewhat elusive construct. Thus, Marsh and Roche (1997) insisted that any proposed indicators of teaching quality must be corroborated through construct-validity testing. Furthermore, the authors stressed that being able to link a construct with measurable classroom processes is an essential requisite for evidence of such a construct's validity. 
Hobson and Talbot (2001) summarized much of the argument by observing, "Validity refers to the extent to which student evaluations actually measure what they are intended to measure--instructor effectiveness. Validity, however, is especially difficult to establish because researchers concede that there is no universally accepted criteria for what constitutes effective teaching" (p.4). Perhaps as Marsh and Bailey (1993) pointed out, the problem of validity lies with the adequacy of the construct. Because the act of teaching is multidimensional, the authors emphasize that for such an instrument, validity should be established through a construct-validation method that reflects the complexity of the act of teaching.

Nevertheless, for the past decade much of the controversy has appeared to revolve around the potential bias resulting from extraneous factors. For example, Greenwald (1997) maintained that the relatively extensive body of research from the 1970s that provided the basis for the acceptance of student ratings of instruction never settled the question of discriminant validity, or the possibility of bias caused by external variables that have nothing to do with teaching effectiveness. Thus, Greenwald argued that this occurred primarily because of the researchers' predisposition to treat their findings on convergent validity, or the correlation of those ratings with other indicators of effective teaching, as satisfactory evidence of the overall validity of students' evaluations of effective teaching.

\section{Perceived Instructor Leniency}

Another concern that has received much attention throughout the last decade is the effect of instructor leniency, on the way that students rate them. According to the critics, these extraneous variables can take the form of (a) lenient grading, (b) light course 
workload and perceived low level of difficulty, or (c) a combination of the two. A little over a decade ago, Greenwald and Gillmore (1997) revived this controversy with a new study, which tended to refute the commonly-held beliefs that there is no significant correlation between perceived leniency and the rating of the instructor. The authors' disagreement with the predominant views in the literature were based on their findings that it was not simply a question of expected grades, but the perception of low or high course workload that affected how the students rated their professors. Greenwald and Gillmore maintained that it was the absence of this newly-introduced course workload variable that flawed previous studies.

This course workload theory was subsequently challenged by Marsh and Roche (2000) in a widely-circulated article, with their assertions that purported bias due to grading leniency and low workload were just a myth. In this article, the authors cited about two decades-worth of studies that allegedly tended to debunk the instructor leniency theories, and also reexamined Greenwald and Gillmore's (1997) study. In their closing critique, Marsh and Roche underscored the multidimensionality of the act of teaching, insisting that simple correlations lead to conflicting interpretations. Thus, they advocated a construct-validity approach for future studies, which would more accurately examine the relationship among multiple background variables, and better assist in identifying and controlling potential biases.

Nevertheless, the bias controversy continues to this day, with a number of studies taking sides with Greenwald and Gillmore's (1997) assertions of systematic bias, stemming from perceived levels of instructor leniency and course difficulty (Olivares, 2001; Griffin, 2004; Isely \& Singh, 2005; Addison, Best, \& Warrington, 2006; Guinn \& 
Vincent, 2006), if perhaps in slightly different forms. On the other hand, also standing prominently among those who dispute the existence of this bias in student evaluations is Centra (2003). After conducting a metanalysis of student evaluations comprising over 50,000 courses across disciplines at various institutions, the author affirmed that there was no evidence to suggest bias due to grades or course workload, concurring with Marsh and Roche's (2000) findings. Other studies conducted during this decade, which support the position that any potential evidence of bias found is not statistically significant, include Heckert, Latier, Ringwald-Burton \& Drazen's (2006), and Lesser and Ferrand's (2000).

\section{Gender Preferences}

Another issue that has re-emerged in the literature is the influence of the gender of both student and instructor, on how the instructor is rated. Although the consensus from the studies carried out throughout 1970s and 1980s was that there was not sufficient evidence to suggest that gender preferences constituted a validity issue, more recent studies have yielded mixed results. At the heart of that controversy was whether male students tended to rate women faculty lower than men, and whether female students exhibited a preference for women faculty, and the resulting question of whether there is an interaction between the sex of student and instructor, when evaluating the instructor.

Prominent among the proponents of potential gender effects in student evaluations of faculty are Baslow and colleagues, with several studies that span almost a decade. Nevertheless, upon close examination, some of those studies appeared to contradict each other, mainly with respect to the preferences of female students. An early study conducted by Basow and Silberg (1987) suggested that on average, male students rated 
female professors significantly lower than male professors, and female students rated their male and female professors virtually uniformly.

In a subsequent study Basow (2000) concluded that, "male students tend to value (i.e., choose as "best") female professors less, while female students tend to value them more than would be expected" (p. 414). This apparent preference for female faculty on the part of female students is a noteworthy departure from the previous study, in which Basow and Silberg (1987) maintained that there was no significant difference in the way that female students rated both male and female professors.

A few years later, Basow and Montgomery (2005) conducted a more complex study, in which they factored specific types of interactions for both male and female faculty, as well as disciplinary areas. In contrast to previous studies, the authors' findings suggested that female professors were consistently rated higher by both male and female students on the basis of interpersonal communication behaviors, than their male counterparts. Beyond that, the results become mixed when segregated by disciplinary area. If nothing else, the findings of that study suggest that the complexity of the interactions between students and faculty is an area that is still poorly understood, and in need of much more scrutiny.

In a more extensive study $(n=633)$ of the influence of gender and ethnicity on how students rate faculty, Anderson and Smith (2005) stated that while there were student response patterns associated with the teaching style, there were no main effects that could be associated solely with gender preferences, which did not support their hypothesis about gender preferences. Thus, the authors inferred that faculty gender made no difference as to how the students rated their professors. 
The most extensive study probably conducted in this category was Centra and Gaubatz' (2000) metanalysis of faculty evaluations comprising 741 courses from 21 institutions, each containing at least 10 male and 10 female students. Although the authors acknowledge that there was evidence of small effects ostensibly attributable to student-faculty gender factors, they added that those could probably be more satisfactorily explained by the differences in teaching styles.

\section{Summary}

Almost 20years after the original Seven Principles were published, Chickering and Erhmann (1996) readapted them to encompass the emerging instructional technology, including the online electronic classroom. With their reemergence in a slightly different form, the Seven Principles gradually regained prominence as models of best practices for online courses. As such, they become process indicators of good teaching practices, which may allow a researcher to measure the extent of the instructor's interaction with the students, and the extent to which the instructor has facilitated diverse opportunities for learning. This is particularly important in asynchronous, Internet-based distance education courses, in which instructor and students are separated by both time and distance.

Thus, this study utilized the processes embodied in the Seven Principles, as adapted to the electronic medium, to: (a) develop an alternative instrument with which students in online courses may rate their perceptions of the instructor's performance, and the extent to which the instructor has facilitated their learning, and (b) validate the instrument with a study conducted at a major public university in Florida. 


\section{CHAPTER III}

\section{METHODS}

This study validated a new instrument that students can use to evaluate the perceived teaching effectiveness of the instructor in online courses, based upon Chickering and Gamson's (1987) Seven Principles of good practice in undergraduate education. These principles offer an inventory of teaching practices that contribute to student learning. Thus, the Seven Principles provided operational definitions for the construct, "effective teaching." The study seeked to, (a) determine the latent structure underlying the items in the instrument through an exploratory factor analysis, (b) gather and ascertain evidence for construct validity of the instrument and internal consistency of the factors derived from the Seven Principles that are obtained through the exploratory factor analysis, and (c) examine the potential effects of student-instructor gender, perceived instructor leniency, and perceived workload.

\section{Research Questions}

The study seeks answers to the following questions:

1. Is the underlying factor structure of the new instrument consistent with the Chickering and Gamson's (1987) Seven Principles?

2. Is the factor structure of the new instrument invariant for male and female students?

3. Are the scores on the new instrument related to the grades that the students expect in the course?

4. Are the scores on the new instrument related to the students' perceived workload in the course? 


\section{Sample}

The sampling frame for this study contained over 300 undergraduate online courses, representing approximately 90 academic units at a major research public university. A cluster sample was selected, consisting of a total of 43 courses across the disciplines, over two consecutive semesters, whose instructors consented to the posting of the instrument in their courses. The average enrollment for online courses at this institution is approximately 30 students per course, notwithstanding that some instructors combine two courses into a single section for convenience. Thus, the total sample included well over 1,290 students. Ultimately, 297 students responded and provided useful responses. This produced a response rate that was somewhat under $23 \%$.

The question of the appropriate minimum sample size for a factor analysis is somewhat contentious, ranging from a minimum of as little as two participants for each variable (Kine, 1979), to five to one (Bryant and and Yarnold, 1995), to ten to one (Nunnally, 1978). Thus, given the 25 variables in the study, the 11.9 to 1 ratio of respondents to variables appears to be adequate for an exploratory factor analysis. All the students registered in each course selected were asked to rate their instructors with the newly developed instrument.

A cluster sample is a variation of simple random sampling, in which groups of participants, rather than individuals, are selected. Gay and Airasian (2000) stated that this method is particularly useful for educational research settings, where extracting individuals from a classroom setting is typically not feasible, also affirming that a random selection of multiple clusters is generalizable to the population being studied. The cluster 
sample method was chosen for the study because the researcher had to secure the instructor's approval for each course surveyed, prior to making the selection.

\section{Procedure}

The instructors of record for all the online courses were contacted by the researcher and asked to cooperate by allowing students in their courses to choose whether or not to participate in the study. The instructor then posted a message to all the students, asking them to participate on a voluntary basis. A notice explaining the voluntary nature of the survey was posted prominently within either the Blackboard or Moodle environments of each course selected within four weeks of the end of the semester, again asking the students to participate. The notice contained the link to the online instrument at a remote server, to protect the identity of respondents. Although the individual courses selected were identified on a list, no attempt was made to identify the individual participants, or the participants from non-participants within each course. The role of the instructor was limited to sending a reminder to all the students in the course, asking for their cooperation if they had not yet completed the instrument.

No personal information that may have been linked back to the respondent was asked on the questionnaire, other than the sex of the participant. The Online Teaching Effectiveness Instrument was loaded onto a secure server maintained at Washington State University in cooperation with the TLT group, better known as Flashlight Online, in which the results are password-protected by the researcher. The students were provided with link to access the instrument that was posted within each course. A pilot was conducted approximately two weeks prior to the beginning of the 
study with a group of undergraduate students, to insure that there were no technological problems, and that the questions were clearly understood.

The students enrolled in the online courses then used the link provided to fill out the blank online questionnaire. Although this did not insure that individual students may have filled out more than one questionnaire, it insured that only those students enrolled in the course could do so. As soon as a questionnaire was submitted, the data were collected in a password-protected database which only the researcher could access. The analyzed

results, including those by gender were only published in global form, without identifying the specific courses surveyed. As far as the instructor is concerned, he or she may only receive the global results for the course upon request, and only after final grades were issued to the students.

\section{Instrumentation}

The items in the instrument were selected from the inventories of constructive instructor behaviors in online courses, identified in Chickering and Ehrmann's (1996) adaptation of the Seven Principles, Phipps and Merisotis' (2000), and the Graham et al. (2001) studies. As a result of this selection procedure, 26 individual items were constructed. This procedure makes the inventory consistent with a large part of the theoretical base on student evaluation of instruction and makes the scores obtained from the instrument more interpretable. This procedure is demonstrated in Table 1.

In addition, two demographic items, and one item asking students to indicate their perception of the workload required in the course and their expected grades were included. The students accessed the instrument directly from a hyperlink posted within 
the course, which took them outside the Blackboard or Moodle course environment, to a remote server that was be under the control of the researcher.

The students then rated the instructor behaviors on a four-point Likert scale.

Those questions were structured to address the instructor's observance of each of the Seven Principles as follows: questions 3 through 5 with respect to, "encourages contacts between students and faculty;" questions 6 to 10 with respect to, "develops reciprocity Table 1 Comparison of Recommended Classroom Processes Derived from the Seven Principles

\begin{tabular}{|c|c|c|c|c|}
\hline $\begin{array}{l}\text { Chickering \& } \\
\text { Gamson's Seven } \\
\text { Princinles }\end{array}$ & $\begin{array}{l}\text { Chickering \& } \\
\text { Gamson (1987) }\end{array}$ & $\begin{array}{l}\text { Chickering \& } \\
\text { Ehrmann (1996) }\end{array}$ & $\begin{array}{l}\text { Graham et al. } \\
(2000)\end{array}$ & $\begin{array}{l}\text { Phipps \& Merisotis } \\
(2000)\end{array}$ \\
\hline
\end{tabular}

\begin{tabular}{|c|c|c|c|c|}
\hline $\begin{array}{l}\text { 1. Encourages } \\
\text { contacts between } \\
\text { students and } \\
\text { faculty. }\end{array}$ & $\begin{array}{l}\text { A. Freshman } \\
\text { seminars } \\
\text { B. faculty-led } \\
\text { discussion groups }\end{array}$ & $\begin{array}{l}\text { Frequent use of } \\
\text { email messaging }\end{array}$ & $\begin{array}{l}\text { A. Encourage } \\
\text { private } \\
\text { communication } \\
\text { through emails } \\
\text { B. Provide bulletin } \\
\text { board for shared } \\
\text { messages and } \\
\text { respond with } \\
\text { courtesy to public } \\
\text { messages } \\
\text { C. Share values, } \\
\text { attitudes, and } \\
\text { experiences with } \\
\text { students } \\
\text { D. Provide early } \\
\text { ice-breaker } \\
\text { assignment } \\
\text { designed to help } \\
\text { know each other } \\
\text { better } \\
\text { E. Communicate } \\
\text { email response } \\
\text { policy and timeline } \\
\text { clearly. }\end{array}$ & $\begin{array}{l}\text { Student interaction } \\
\text { with faculty is } \\
\text { facilitated through } \\
\text { a variety of ways }\end{array}$ \\
\hline
\end{tabular}


Table 1 continued

Comparison of Recommended Classroom Processes Derived from the Seven Principles

\begin{tabular}{|c|c|c|c|c|}
\hline $\begin{array}{l}\text { Chickering \& } \\
\text { Gamson's Seven } \\
\text { Principles }\end{array}$ & $\begin{array}{l}\text { Chickering \& } \\
\text { Gamson (1987) }\end{array}$ & $\begin{array}{l}\text { Chickering \& } \\
\text { Ehrmann (1996) }\end{array}$ & $\begin{array}{l}\text { Graham et al. } \\
(2000)\end{array}$ & $\begin{array}{l}\text { Phipps \& Merisotis } \\
(2000)\end{array}$ \\
\hline $\begin{array}{l}\text { 2. Develops } \\
\text { reciprocity and } \\
\text { cooperation among } \\
\text { students. }\end{array}$ & $\begin{array}{l}\text { Learning groups } \\
\text { (to solve problems } \\
\text { assigned by } \\
\text { instructor) }\end{array}$ & $\begin{array}{l}\text { A. Learning teams } \\
\text { B. Collaborative } \\
\text { learning through } \\
\text { electronic } \\
\text { communication }\end{array}$ & $\begin{array}{l}\text { A. Include group } \\
\text { assignments as } \\
\text { part of the course. } \\
\text { B. Include well- } \\
\text { designed } \\
\text { discussion } \\
\text { assignments. } \\
\text { C. Require } \\
\text { assignments that } \\
\text { require meaningful } \\
\text { peer interaction } \\
\text { throughout the } \\
\text { semester } \\
\text { D. Provide for peer } \\
\text { evaluation of } \\
\text { student work. } \\
\text { E. Provide a } \\
\text { mechanism for } \\
\text { evaluating } \\
\text { individual } \\
\text { participation and } \\
\text { contribution to } \\
\text { group projects }\end{array}$ & $\begin{array}{l}\text { A. Student } \\
\text { interaction with } \\
\text { other students is } \\
\text { facilitated through } \\
\text { a variety of ways. } \\
\text { B. Class voice- } \\
\text { mail and/or e-mail } \\
\text { systems are } \\
\text { provided to } \\
\text { encourage students } \\
\text { to work with each } \\
\text { other and their } \\
\text { instructor(s). } \\
\text { C. Course is } \\
\text { designed to require } \\
\text { students to work in } \\
\text { groups utilizing } \\
\text { problem-solving } \\
\text { activities in order } \\
\text { to develop topic } \\
\text { understanding. }\end{array}$ \\
\hline
\end{tabular}

\begin{tabular}{lll}
\hline 3. Uses active & A. Structured class & Internet research- \\
learning & exercises & based projects, \\
techniques. & B. Class & simulation \\
& discussions & software \\
& C. Team projects &
\end{tabular}
A. Create authentic Each assignments and module/segment real-world projects requires students to that require application. B. Completed projects should be presented on bulletin board, providing for peer feedback. C. Provide bulletin board assignments that allow students to challenge ideas.


Table 1 continued

Comparison of Recommended Classroom Processes Derived from the Seven Principles

\begin{tabular}{|c|c|c|c|c|}
\hline $\begin{array}{l}\text { Chickering \& } \\
\text { Gamson's Seven } \\
\text { Principles }\end{array}$ & $\begin{array}{l}\text { Chickering \& } \\
\text { Gamson (1987) }\end{array}$ & $\begin{array}{l}\text { Chickering \& } \\
\text { Ehrmann (1996) }\end{array}$ & $\begin{array}{l}\text { Graham et al. } \\
(2000)\end{array}$ & $\begin{array}{l}\text { Phipps \& Merisotis } \\
\text { (2000) }\end{array}$ \\
\hline $\begin{array}{l}\text { 4. Gives prompt } \\
\text { feedback. }\end{array}$ & $\begin{array}{l}\text { Frequent } \\
\text { assessment and } \\
\text { detailed feedback }\end{array}$ & $\begin{array}{l}\text { A. Enhancing } \\
\text { feedback through } \\
\text { the use of "add } \\
\text { comments" feature } \\
\text { B. Storing all work } \\
\text { in a "portfolio" for } \\
\text { later review }\end{array}$ & $\begin{array}{l}\text { response). } \\
\text { D. Structure } \\
\text { assignments so that } \\
\text { students can } \\
\text { provide feedback to } \\
\text { each other. }\end{array}$ & $\begin{array}{l}\text { A. Feedback to } \\
\text { student assignments } \\
\text { and questions is } \\
\text { provided in a timely } \\
\text { manner. } \\
\text { B. Feedback to } \\
\text { students is provided } \\
\text { in a manner that is } \\
\text { constructive and } \\
\text { non-threatening. } \\
\text { C. Faculty return all } \\
\text { assignments within } \\
\text { a certain time period }\end{array}$ \\
\hline $\begin{array}{l}\text { 5. Emphasizes } \\
\text { time on task. }\end{array}$ & $\begin{array}{l}\text { 1. Mastery } \\
\text { learning } \\
\text { 2. Computer- } \\
\text { assisted } \\
\text { instruction (time) }\end{array}$ & $\begin{array}{l}\text { Allocate realistic } \\
\text { amount of times for } \\
\text { learning }\end{array}$ & $\begin{array}{l}\text { A. Structure } \\
\text { assignments with } \\
\text { specific deadlines } \\
\text { that require regular } \\
\text { participation. } \\
\text { B. Spread deadlines } \\
\text { throughout the } \\
\text { semester to keep } \\
\text { students working. }\end{array}$ & $\begin{array}{l}\text { A. Specific } \\
\text { expectations are set } \\
\text { for students with } \\
\text { respect to a } \\
\text { minimum amount of } \\
\text { time per week for } \\
\text { study and } \\
\text { homework } \\
\text { assignments. }\end{array}$ \\
\hline $\begin{array}{l}\text { 6. Communicates } \\
\text { high } \\
\text { expectations. }\end{array}$ & $\begin{array}{l}\text { Special } \\
\text { workshops }\end{array}$ & $\begin{array}{l}\text { A. Articulate } \\
\text { criteria for } \\
\text { satisfactory work } \\
\text { B. Show examples } \\
\text { of good and poor } \\
\text { work }\end{array}$ & $\begin{array}{l}\text { A. Provide grading } \\
\text { rubric. } \\
\text { B. Provide praise } \\
\text { and call attention to } \\
\text { good work. } \\
\text { C. provide } \\
\text { examples of } \\
\text { exemplary } \\
\text { performance to } \\
\text { students }\end{array}$ & $\begin{array}{l}\text { A. Before starting } \\
\text { the program, } \\
\text { students are advised: } \\
\text { Do they have the } \\
\text { self-motivation and } \\
\text { commitment to learn } \\
\text { at a distance? } \\
\text { B. Learning } \\
\text { outcomes for each } \\
\text { course are } \\
\text { summarized in a } \\
\text { clearly written, } \\
\text { straightforward } \\
\text { statement. }\end{array}$ \\
\hline $\begin{array}{l}\text { 7. Respects } \\
\text { diverse talents } \\
\text { and ways of } \\
\text { learning. }\end{array}$ & $\begin{array}{l}\text { Personalized } \\
\text { system of } \\
\text { instruction. }\end{array}$ & $\begin{array}{l}\text { Provide a variety of } \\
\text { tasks and virtual } \\
\text { experiences (for } \\
\text { slow as well as } \\
\text { bright students) }\end{array}$ & $\begin{array}{l}\text { A. Provide a choice } \\
\text { of project topics. } \\
\text { B. Encourage } \\
\text { students to express } \\
\text { diverse points of } \\
\text { view. } \\
\text { C. Include } \\
\text { exercises that } \\
\text { represent diverse } \\
\text { perspectives. }\end{array}$ & \\
\hline
\end{tabular}


and cooperation among students;" questions 11 to 14 with respect to, "uses active learning techniques;" questions 15 to 18 with respect to, gives prompt feedback;" questions 19 to 21 with respect to, "emphasizes time on task;" questions 22 to 24 with respect to, "communicates high expectations;" and questions 25 to 28 with respect to, "respects diverse talents and ways of learning." Additionally, the students were asked to

indicate: (a) their sex, (b) the instructor's sex, (c) the perceived extent of the workload in the course, and (d) the approximate final grade that they expected in the course. Only the researcher had access to the data stored on the server, and all the data was permanently removed upon the conclusion of the study.

\section{Data Analysis}

A number of data analysis strategies were used to answer the research questions. This section is organized so that it is clear which research question was addressed in the ongoing data analysis.

Research Question \#1: Is the underlying factor structure of the new instrument consistent with Chickering and Gamson's (1987) Seven Principles?

An exloratory factor analysis using principle components extraction and a Varimax rotation was conducted to obtain the underlying structure of the instrument..Varimax rotation was chosen because it is an orthogonal rotation that minimized the complexity of the obtained factors by maximizing the variance of the loadings on each factor. The goal of this analysis was to obtain a seven-factor structure that could be compared to the Seven Principles. The factor structure was examined to determine whether it reflected the Seven Principles. Then, each of the scores within each 
of the seven factors yielded by the principal component analysis was examined using Cronbach's Alpha, to determine the internal consistency.

Research Question \#2: Is the factor structure of the new instrument invariant for male and female students?

The original sample was divided in two based on the sex of the respondent. Factor matching was then used to determine whether factors that were similar based on the results of the original exploratory factor analysis had similar factor structures for the men and women in the sample.

Research Question \#3: Are the scores on the new instrument related to the grades that the students expect in the course?

A series of rank-biserial correlations (Cureton, 1956, 1968; Hinkle, Wiersma, \& Jurs, 2003) were calculated to determine the relationship between respondents' scores on each of the factors underlying the instrument and respondents' expected grades for the course. The hypothesis that $r_{r b}>0$ was tested at the $\alpha=.05$ level of significance for each factor. The probability of detecting a correlation of $r_{r b}=.15$ with $n=300$ and $\alpha=.05$ was .83.

4. Are the scores on the new instrument related to the students' perceived workload in the course?

Similar to the strategy used to answer Research Question \#3, a series of rankbiserial correlations were calculated to determine the relationship between respondents' scores on each of the factors and the level of the workload reported by participants. The hypothesis that $r_{r b}>0$ was tested at the $\alpha=.05$ level of significance for each factor. 


\section{CHAPTER IV}

\section{RESULTS}

The Online Teaching Effectiveness Instrument was loaded onto a secure server maintained at Washington State University in cooperation with the TLT group, better known as Flashlight Online. This server is specifically intended for administering student online course evaluations, and made available to member institutions.

The instrument was first tested in a pilot study at a large public university in Florida during the summer 2009 term, and made available online to students in a single online course. A link that took students directly to the secure server was established within the online course with the appropriate announcement inviting the students to participate voluntarily, and the instructor was asked to encourage the students to participate in the survey. This first study yielded 42 useable responses that were saved for future use in the data analysis

A second study was conducted during the fall 2009 term, in a random selection of all undergraduate online courses offered by the institution, yielding 141 useable responses. The third and final study was conducted during the spring 2010 term with a random selection of all the undergraduate online courses, yielding 126 useable responses. All responses were subsequently merged into a single SPSS data set for analytical purposes.

The students responded to items 3 to 28 of the instrument on a Likert scale, to indicate the extent of their agreement with the items that described the online instructor's best practices as defined by the Seven Principles. The students also indicated their sex, 
the sex of the instructor, the final grade they expected in the course, and the perceived level of difficulty of the course.

\section{Research Question 1:}

An exploratory factor analysis using a principal component extraction with a Varimax rotation yielded a seven-factor solution that closely paralleled the Seven Principles advocated by Chickering and Gamson (1987), and accounted for over $76 \%$ of the variance of items 3 to 28 in the instrument. See Appendix B for the factor loadings.

\section{The Underlying Structure of the Online Teaching Effectiveness Instrument}

The first of the seven factors accounted for $18.17 \%$ of the total variance and described a measure of the extent that the instructor engages the students in the learning process, expressed as Time on Task, which parallels principle five of the Seven Principles. The second factor accounted for $12.39 \%$ of the total variance and described a measure of how well the instructor developed reciprocity and cooperation among students, expressed as Develops Cooperation, which parallels principle two. The third factor accounted for $11.37 \%$ of the total variance and described a measure of how well the instructor encouraged the students to contact him or her, expressed as Student Contact, which parallels principle one.

The fourth factor accounted for $9.58 \%$ of the total variance and described a measure of the instructor's efforts to include a variety of instructional materials to accommodate different styles of learners, expressed as Diverse Learning, which parallels principle seven. The fifth factor accounted for $9.26 \%$ of the total variance and described a measure of how well the instructor communicates his or her high expectations for student performance in the course, expressed as High Expectations, which parallels principle six. 
Table 2

Loadings of the Three Definitive Items in Each of the Online Teaching Effectiveness Instrument's Seven Factors

\begin{tabular}{|c|c|c|c|c|c|c|c|}
\hline \multirow[b]{2}{*}{ Item } & \multicolumn{7}{|c|}{ Loadings } \\
\hline & Time on & Develops & Student & Diverse & High & Prompt & Active \\
\hline 19. There is enough work in this course to keep me busy... & .821 & .025 & .161 & .065 & .164 & -.224 & .113 \\
\hline 27. I am given a sufficient window of time to complete the assignments & .740 & .223 & .147 & .164 & .099 & .183 & .216 \\
\hline 15. I can easily find out when all the assignments are due & .730 & .074 & .197 & .117 & .172 & .412 & .021 \\
\hline $\begin{array}{l}\text { 9. The instructor encourages students to help each other in this course } \\
\text { 10. Some of my fellow students have been very supportive of me in this }\end{array}$ & .178 & .798 & .136 & .207 & .118 & .143 & .088 \\
\hline course & .082 & .792 & -.035 & -.001 & .094 & .111 & .282 \\
\hline $\begin{array}{l}\text { 8. I am familiar with the work that some of the other students have } \\
\text { done in this course }\end{array}$ & .063 & .761 & .124 & .190 & .018 & -.091 & .184 \\
\hline $\begin{array}{l}\text { 4. I have a good idea of how long it will take the instructor to respond } \\
\text { to my messages }\end{array}$ & .066 & .169 & .807 & .234 & .120 & .312 & .061 \\
\hline 5. I am satisfied with the instructor's response time... & .419 & .129 & .788 & .129 & .135 & .129 & .147 \\
\hline 3. My instructor is very accessible through email & .425 & .111 & .763 & .042 & .133 & .170 & .125 \\
\hline $\begin{array}{l}\text { 28. In this course I have learned in other ways than... } \\
\text { 14. The links to other information provided in this course have been }\end{array}$ & .209 & .088 & .175 & .842 & .107 & .071 & .145 \\
\hline helpful to me & .059 & .375 & .208 & .587 & .158 & .205 & .361 \\
\hline 26. I have found review materials... to be helpful & .162 & .152 & .031 & .519 & .296 & .458 & .273 \\
\hline expectations & .273 & .048 & .046 & .099 & .845 & -.011 & .162 \\
\hline 22. I think I know what my instructor expects of me... & .198 & .159 & .176 & .166 & .842 & .189 & .060 \\
\hline 21. I believe that my instructor values hard work & .060 & .112 & .359 & .286 & .532 & .433 & .150 \\
\hline $\begin{array}{l}\text { 1/. I am satisfied with the instructor's turnaround time for the } \\
\text { assignments }\end{array}$ & .170 & .060 & .333 & .193 & .118 & .786 & .170 \\
\hline 16. I have received my grades for quizzes and assignments promptly & .567 & .006 & .367 & .039 & .000 & .574 & .567 \\
\hline 18. The instructor offers useful feedback & .134 & .250 & .414 & .475 & .273 & .492 & .134 \\
\hline 12. I have learned new things by conducting... research & .017 & .311 & .101 & .173 & .138 & .120 & .770 \\
\hline 11. I have learned new things by doing them... & .527 & .320 & .139 & .296 & .058 & .070 & .512 \\
\hline 13. I believe... assignments in this course help me learn useful... & .471 & .300 & .114 & .385 & .180 & .185 & .462 \\
\hline
\end{tabular}


The sixth factor accounted for $9.16 \%$ of the total variance and described a measure of the promptness with which the instructor offers feedback to the students, expressed as Prompt Feedback, which parallels principle four. The seventh factor accounted for $6.93 \%$ of the total variance and described a measure of the instructor's efforts to engage the students in active learning, described as Active Learning, which parallels principle three.

\section{Measures of Reliability}

The internal consistency of each of the scores within each of the seven factors yielded by the principal component analysis was examined using Cronbach's Alpha. The values obtained were: (a) $r_{\alpha}=.887$ for Time on Task, (b) $r_{\alpha}=.828$ for Develops Cooperation, (c) $r_{\alpha}=.907$ for Student Contact, (d) $r_{\alpha}=.784$ for Diverse Learning, (e) $r_{\alpha}=$ .816 for High Expectations, (f) $r_{\alpha}=.828$ for prompt feedback, and (g) $r_{\alpha}=.794$ for Active Learning.

\section{Research Question 2:}

Two separate principal components factor analyzes were conducted to determine if the seven-factor structure yielded by the original analysis was invariant for male and female students. The two analyses showed different factor structures for the two sexes (see appendices $\mathrm{C}$ and $\mathrm{D}$ ).

Nevertheless, closer examination revealed that although the factor structures appeared to be different for men and women at first sight, there were ten items that could be realigned under four of the original factors from the principal component extraction for both men and women (Table 3). A second phase of the analysis was carried out by comparing the factor structures for both men and women (see appendices $\mathrm{C}$ and $\mathrm{D}$ ) 
revealed that those ten items appeared together within a single factor for both men and women.

For example, items I11, I15, I19, and I27 appeared together in factor one for the women, and factor two for the men. Likewise, I8, I8, and I10 appeared together in factor two for men, and factor four for women. Similarly, I17 and I18 appeared together in factor three for men, and factor five for women. Also, I3, I4, and I5 appeared together in factor four for men, and factor one for women. Finally, I22 and I23 appeared together in factor five for men, and factor six for women.

Table 3

Male and Female Students Factors Descriptive Statistics

\begin{tabular}{|c|c|c|c|c|c|}
\hline \multicolumn{3}{|c|}{$\underline{\text { Women }(n=214)}$} & \multicolumn{3}{|c|}{$\underline{\operatorname{Men}(n=83)}$} \\
\hline Item & $M$ & $S D$ & Item & $M$ & $S D$ \\
\hline \multicolumn{6}{|c|}{ Student contact } \\
\hline $\mathrm{I} 3$ & 3.37 & .718 & $\mathrm{I} 3$ & 3.33 & .767 \\
\hline $\mathrm{I} 4$ & 3.35 & .766 & I4 & 3.18 & .829 \\
\hline I5 & 3.29 & .769 & I5 & 3.25 & .778 \\
\hline \multicolumn{6}{|c|}{ Develops cooperation } \\
\hline I8 & 2.69 & 1.046 & I8 & 2.74 & .914 \\
\hline I9 & 2.90 & .910 & I9 & 2.76 & .910 \\
\hline $\mathrm{I} 10$ & 2.68 & .948 & $\mathrm{I} 10$ & 2.65 & .935 \\
\hline \multicolumn{6}{|c|}{ Prompt feedback } \\
\hline $\mathrm{I} 17$ & 3.52 & .707 & $\mathrm{I} 17$ & 3.31 & .815 \\
\hline $\mathrm{I} 18$ & 3.39 & .770 & $\mathrm{I} 18$ & 3.14 & 1.019 \\
\hline \multicolumn{6}{|c|}{ High expectations } \\
\hline $\mathrm{I} 22$ & 2.92 & .757 & $\mathrm{I} 22$ & 2.82 & .843 \\
\hline $\mathrm{I} 23$ & 2.97 & .754 & $\mathrm{I} 23$ & 3.02 & .811 \\
\hline \multicolumn{6}{|c|}{ Assignments and course work } \\
\hline I19 & 3.38 & .832 & $\mathrm{I} 19$ & 3.44 & .890 \\
\hline $\mathrm{I} 15$ & 3.50 & .659 & $\mathrm{I} 15$ & 3.49 & .671 \\
\hline $\mathrm{I} 27$ & 3.13 & .982 & $\mathrm{I} 27$ & 3.09 & .932 \\
\hline $\mathrm{I} 11$ & 3.09 & .877 & $\mathrm{I} 11$ & 3.18 & .833 \\
\hline
\end{tabular}


Of those five factors that emerged, the four that match the factors in the original principle component analysis are, student contact, develops cooperation, prompt feedback, and high expectations. The fifth factor actually combines items from time on task, active learning, and diverse learning. However, the items are directly related to assignments and course work; thus, they were interpreted more generally as comprising assignments and course work.

Specifically, the first three items of factor one for the female students correspond with the first three items of factor two for the male students, both comprising assignments and coursework. Likewise, the first three items of factor four for women correlate with the first three items of factor one for men, comprising communication. Similarly, the three items comprising cooperation correspond for both male and female students. Two other items comprising instructor feedback and high expectations respectively, aligned for both male and female students for both feedback and high expectations (see Table 3).

In addition, there were four related items pertaining to assignments and course work from two of the other factors for men and women, which were realigned to comprise a slightly broader factor. These items were, I11, "I have learned new things by doing them, not just by reading about them;" I15, "I can easily find out when all the assignments are due;" I19, "There is enough work in this course to keep me busy for three hours per week;" and I27, "I am given a sufficient window of time to complete the assignments." Because of their similarities, they were regrouped in a new factor with the name of Assignments and Course Work (Table 3). 
Reliability analyses for the scores for men and women comprising those three items, using Cronbach's Alpha (Table 4) yielded comparatively high values for both sexes $\left(r_{\alpha}=.911\right.$ for men, and $r_{\alpha}=.832$ for women $)$; therefore, although the factor structures as wholes differ, the items that were matched for four of the factors are consistent for both men and women within their respective factors.

Table 4

Reliability Analysis of Factors for Men and Women

\begin{tabular}{lcc}
\hline \multicolumn{1}{c}{ Factor } & Men & Women \\
\hline Assignments and course work & $r_{\alpha}=.911$ & $r_{\alpha}=.832$ \\
Communication & $r_{\alpha}=.904$ & $r_{\alpha}=.883$ \\
Feedback & $r_{\alpha}=.865$ & $r_{\alpha}=.842$ \\
Cooperation & $r_{\alpha}=.835$ & $r_{\alpha}=.821$ \\
High Expectations & $r_{\alpha}=.848$ & $r_{\alpha}=.840$ \\
\hline
\end{tabular}

When only the 14 items identified in Table 3 were entered in three principal components factor analyses with varimax rotations using all participants, only men, and only women, respectively and restricting the factor structure to five factors, the factor structures in Tables 5 to 7 were obtained. 
Table 5

Factor Structure of the Second Phase of the Analysis (All Participants)

\begin{tabular}{rccccc}
\hline Item & \multicolumn{5}{c}{ Factors } \\
\hline & $\begin{array}{c}\text { Assignments } \\
\text { and } \\
\text { Coursework }\end{array}$ & Cooperation & Communication & Feedback & High Expectations \\
\hline 19 & .832 & .052 & .208 & -1.76 & .192 \\
27 & .773 & .238 & .208 & .220 & .139 \\
15 &. $\mathbf{7 0 5}$ & .028 & .224 & .447 & .180 \\
11 &. $\mathbf{6 2 3}$ & .476 & .139 & .206 & .135 \\
10 & .113 &. $\mathbf{8 5 3}$ & -.001 & .075 & .081 \\
8 & .081 & .834 & .178 & -.035 & .032 \\
9 & .158 & .774 & .139 & .244 & .143 \\
5 & .384 & .149 & .821 & .190 & .142 \\
4 & .031 & .165 & .807 & .409 & .117 \\
3 & .402 & .092 & .791 & .194 & .125 \\
17 & .172 & .078 & .287 &. $\mathbf{8 4 5}$ & .086 \\
18 & .079 & .246 & .399 & .711 & .264 \\
23 & .237 & .082 & .085 & .049 & .903 \\
22 & .158 & .156 & .187 & .234 & $\mathbf{. 8 6 1}$ \\
\hline$\lambda$ & 2.65 & 2.46 & 2.44 & 1.91 & 1.82 \\
\hline
\end{tabular}

These five factors accounted for $80.55 \%$ of the variance in the instrument scores. The factor structure for the men in the sample is presented in Table 6. 
Table 6

Factor Structure of the Second Phase of the Analysis (Men Only)

\begin{tabular}{|c|c|c|c|c|c|}
\hline \multirow[t]{2}{*}{ Items } & \multicolumn{5}{|c|}{ Factors } \\
\hline & Communication & $\begin{array}{l}\text { Assignments } \\
\text { and } \\
\text { Coursework }\end{array}$ & Cooperation & Feedback & High Expectations \\
\hline 5 & .823 & .354 & .067 & .162 & .220 \\
\hline 4 & .776 & .054 & .193 & .454 & .102 \\
\hline 3 & .766 & .425 & .084 & .263 & .140 \\
\hline 19 & .276 & .810 & .032 & -.065 & .181 \\
\hline 11 & -.035 & .768 & .368 & .247 & .033 \\
\hline 27 & .363 & .723 & .151 & .127 & .333 \\
\hline 15 & .375 & .600 & .087 & .386 & .124 \\
\hline 8 & .201 & .080 & .856 & -.088 & .111 \\
\hline 10 & -.165 & .149 & .795 & .200 & .105 \\
\hline 9 & .312 & .173 & .775 & .210 & .138 \\
\hline 17 & .224 & .197 & .104 & .836 & .143 \\
\hline 18 & .371 & .080 & .141 & .717 & .265 \\
\hline 23 & .072 & .269 & .105 & .137 & .890 \\
\hline 22 & .260 & .110 & .218 & .227 & .842 \\
\hline$\lambda$ & 2.64 & 2.63 & 2.27 & 1.91 & 1.87 \\
\hline
\end{tabular}

These five factors accounted for $80.83 \%$ of the variance in the instrument scores.

The factor structure for the women in the sample is presented in Table 7. 
Table 7

Factor Structure of the Second Phase of the Analysis (Women Only)

\begin{tabular}{|c|c|c|c|c|c|}
\hline \multirow[t]{2}{*}{ Items } & \multicolumn{5}{|c|}{ Factors } \\
\hline & Cooperation & $\begin{array}{l}\text { Assignments } \\
\text { and } \\
\text { Coursework }\end{array}$ & Communication & Feedback & High Expectations \\
\hline 10 & .874 & .099 & .062 & .032 & .053 \\
\hline 8 & .836 & .067 & .183 & -.011 & .044 \\
\hline 9 & .784 & .161 & .065 & .267 & .126 \\
\hline 19 & .067 & .830 & .189 & -.227 & .212 \\
\hline 27 & .271 & .783 & .166 & .246 & .077 \\
\hline 15 & .017 & .728 & 213 & .441 & .206 \\
\hline 11 & .520 & .558 & .232 & .175 & .181 \\
\hline 4 & .163 & -.008 & .826 & .377 & .117 \\
\hline 5 & .180 & .372 & .816 & .208 & .117 \\
\hline 3 & .097 & .377 & .807 & .157 & .106 \\
\hline 17 & .067 & .163 & .321 & .840 & .061 \\
\hline 18 & .298 & .064 & .407 & .717 & .271 \\
\hline 23 & .073 & .207 & .087 & .010 & .908 \\
\hline 22 & .142 & .156 & .150 & .236 & .868 \\
\hline$\lambda$ & 2.61 & 2.56 & 2.50 & 1.90 & 1.84 \\
\hline
\end{tabular}

These five factors accounted for $81.52 \%$ of the variance in the instrument scores.

A series of reliability analyses using Cronbach's Alpha was also conducted to examine the internal consistency of all the scores within each of the five factors from the three separate principal component analyses, which yielded high values indicating internal consistency across sexes (Table 8).

Table 8

Reliability Analysis of Factors

\begin{tabular}{lccc}
\hline Factor & All & Men & Women \\
\hline Communication & $r_{\alpha}=.907$ & $r_{\alpha}=.898$ & $r_{\alpha}=.904$ \\
Cooperation & $r_{\alpha}=.818$ & $r_{\alpha}=.821$ & $r_{\alpha}=.825$ \\
Feedback & $r_{\alpha}=.793$ & $r_{\alpha}=.726$ & $r_{\alpha}=.824$ \\
High Expectations & $r_{\alpha}=.853$ & $r_{\alpha}=.856$ & $r_{\alpha}=.848$ \\
Assignments and Course Work & $r_{\alpha}=.829$ & $r_{\alpha}=.832$ & $r_{\alpha}=.824$ \\
\hline
\end{tabular}




\section{Research Question 3:}

A Spearman rank order correlation was conducted using the scores for the entire five-factor, 14 item instrument and the expected final grade for all the students in the course to establish if there is relationship between the expected grades and the students' responses to the instrument. Spearman's rank order correlation was used because expected grade is an ordinal variable. The results $\left(\rho_{s}=.270, p<.001\right)$ indicate a weak relationship between that variable and the entire instrument.

\section{Research Question 4:}

A Spearman rank order correlation was conducted between the scores for the entire five-factor, 14 item instrument and the perceived workload for the course, to determine if there is a relationship between the two. Spearman's rank order correlation was used because expected grade is an ordinal variable. The results show no evidence of any relationship $\left(\rho_{s}=.017, p=.761\right)$.

\section{Summary}

For research question one, an exploratory factor analysis using a principal component extraction with a Varimax rotation yielded a seven-factor solution that closely paralleled the Seven Principles proposed by Chickering and Gamson (1987), and accounted for over $76 \%$ of the variance of items 3 to 28 in the instrument. The first factor parallels principle five, expressed as, Emphasizes Time on Task, in the original document. The second factor corresponds with principle two, expressed as, Develops Reciprocity and Cooperation Among Students. The third factor parallels principle one, expressed as, Encourages Contacts Between Students and Faculty. The fourth factor parallels principle seven, expressed as, Respects Diverse Talents and Ways of Learning. 
The fifth factor parallels principle six, expressed as, Communicates High Expectations. The sixth factor parallels principle four, expressed as, Gives Prompt Feedback. The seventh factor parallels principle three, expressed as, Uses Active Learning Techniques.

For research question two, two separate principal components factor analyzes were conducted to determine if the seven-factor structure yielded by the original analysis was invariant for male and female students. The results showed different factor structures for both sexes. However, it became evident upon closer examination that most factors were partially consistent for both men and women, given that at least two or three items aligned respectively for both sexes, in five different factors. Ultimately, the differences in the different structures could be the result of differences in perceptions between men and women.

For research question three, a Spearman rank order correlation was conducted using the scores for the entire instrument, and the expected final grade for all the students in the course on an ordinal scale. The results indicate a weak relationship between the total scores and the expected grade variable.

For research question four, a Pearson's correlation was conducted between the scores for the entire instrument and the perceived workload for the course. There appeared to be no significant relationship between these variables. 


\section{CHAPTER V}

\section{DISCUSSION AND RECOMMENDATIONS}

This study provided evidence for the validity of the Online Teaching Effectiveness Instrument (OTEI), an alternative instrument designed to measure students' perceptions of the instructors' effectiveness in online courses, based upon Chickering \& Gamson's ( 1987) Seven Principles of Good Practice for Undergraduate Education. The instrument was administered to a sample of 309 undergraduate students enrolled in online courses at a large public university in Florida.

\section{Discussion}

\section{Factor Structure For All Students}

The exploratory factor analysis of the scores for men and women yielded a sevenfactor solution. Those seven factors matched all the original Seven Principles (Chickering \& Gamson, 1987), with the only difference being the order in which they were extracted, which was somewhat different from the way the authors had originally arranged them. Thus, the factors could be suitably named with abbreviations of the principles originally named by Chickering and Gamson.

Furthermore, these factors also exhibited a high internal consistency for the combined scores for male and female students. Thus, the first part of the study supports the hypothesis that the underlying structure of the OTEI instrument is consistent with six of Chickering and Gamson's Seven Principles.

\section{Factor Structure for Men and Women}

The factor structures that emerged in the separate analyses for men and women appeared at first to be completely different. However, the realignment and matching of 
the items that were common to both men and women yielded four factors that corresponded directly with four of the seven principles. Those factors were named: (a) communication, containing three items and aligning with, encourages contact between student and faculty; (b) cooperation, containing three items and aligning with, develops reciprocity and cooperation among students; (c) feedback, containing two items and aligning with, gives prompt feedback; and (d) high expectations, containing two items and aligning with, communicates high expectations. In addition, there was a fifth factor that contained four items. Three were from the three remaining Seven Principles, and one was from the original feedback factor; it was named assignments and course work.

Communication. This factor aligns with the first of Chickering and Gamson's (1987) Seven Principles. It contains three items that address the extent of student satisfaction regarding communication with the instructor. Specifically, the items comprise measurements of the perceived accessibility of the instructor, and the timeliness of responses to messages from students. All three items had comparably high loadings in the component extractions for both men and women, and had high values for internal consistency.

Moreover, these findings are consistent with the results of Borstorff and Lowe's (2007) study, in which $90 \%$ of the students surveyed responded that interaction with the instructor was of "vital importance" (p. 23) in online courses. Furthermore, these data support Sher's (2009) results, which suggested that the extent of the interaction between instructor and student has a significant influence in perceptions of satisfaction and learning for students in online courses. 
Cooperation. This factor aligns with the second of Chickering and Gamson's (1987) Seven Principles. It contains three items that address the extent to which the instructor has encouraged cooperation among the students. Specifically, the items measure perceptions of how well the instructor has encouraged the students to help each other, the support received from peers, and the sharing of completed work among students. All three items had comparably high loadings in the components extracted for both men and women.

Moreover, these findings are in line with the results of Paechter, Maier, and Macher's (2010) large study $(n=2,196)$ of students' expectations in online courses. As part of their inferences, these authors maintained that providing opportunities for collaborative learning acts as a motivator for a significant number of students, shapes impressions of a positive experience in online courses, and is one of four predictors of both perceptions of learning and satisfaction with the course.

Feedback. This factor aligns with the fourth of Chickering and Gamson's (1987) Seven Principles. It contains two items that address the extent of student satisfaction regarding the timeliness and adequacy of the feedback received from the instructor. Specifically, the items measure perceptions of the turnaround time for assignments submitted, and the usefulness of the feedback that the instructor has offered. Both items had comparably high loadings in the components extracted for both men and women.

These findings are consistent with the importance that a number of authors attach to timely feedback in terms of student satisfaction (Rucker \& Thompson; 2003, Brosvic \& Epstein, 2007; and Dennen, Darabi, \& Smith, 2007, among others). Furthermore, as a result of their qualitative study of students in online courses, Hara and Kling (2001) made 
a case for lack of timely feedback from the instructor as an important source of frustration with the course and dissatisfaction with the instructor.

High expectations. This factor aligns with the fourth of Chickering and Gamson's (1987) Seven Principles. It contains two items that address the extent to which the instructor has communicated high expectations for their performance in the course to the students. Specifically, the items measure perceptions of how well students understand what the instructor expects of them, and how hard they worked in the course to meet the instructor's expectations. Both items had comparably high loadings in the components extracted for both men and women.

These findings are consistent with the results of studies that have linked the communication of high expectations to the students, with students' self-reported gains in the course (Kuh, Laird, \& Umbach, 2004; and Ryan, 2005, among others).

Assignments and course work. This factor contains items from four of the original Seven Principles proposed by Chickering and Gamson (1987). Nevertheless, the four items are descriptive of tasks that accomplish the completion of assignments and other course work. Specifically, the items measure the extent of active learning, the familiarity with assignment deadlines, the perceived workload, and the perceived adequacy of the time allowed for completion of the assignments.

Taken together, these items tend to support the findings of Morris, Finnegan, and Wu's (2005) study of courses offered by the University System of Georgia, in which they investigated what influenced the successful completion of online courses. In this study, the authors found that only approximately $60 \%$ of the students completed the course successfully, and that approximately $40 \%$ of the students either failed or withdrew. 
Interestingly, Morris, Finnegan, and Wu's analysis indicated that the two main predictors of achieving a final passing grade were student participation in online discussions, and their engagement in other forms of other online course work. Thus, the results of Morris, Finnegan and $\mathrm{Wu}$, suggest that providing sufficient opportunities for engagement through assignments and course work, correlates with the students' successful completion of their online courses.

\section{Recommendations}

A recommendation came forward out of this study, with regard to the items in the original instrument.

The variation in the factor structure between men and women led to the identification of five factors containing a total of 14 items (Table 9) that were shared by both groups in the two separate principal components analyzes.

Table 9

OTEI instrument items in factor structures, shared by both men and women

I3 My instructor is very accessible through email.

I4 I have a good idea of how long it will take the instructor to respond...

I5 I am satisfied with the instructor's response time to my messages.

I8 I am familiar with the work that some of the other students have done...

I9 The instructor encourages students to help each other in this course.

I10 Some of my fellow students have been very supportive of me in this course.

I11 I have learned new things by doing them, not just by reading about them.

I15 I can easily find out when all the assignments are due.

I17 I am satisfied with the instructor's turnaround time for the assignments.

I18 The instructor offers useful feedback.

I19 There is enough work in this course to keep me busy for three hours per week.

I22 I think I know what my instructor expects of me in this course.

I23 I have worked hard in this course to meet my instructor's expectations.

I27 I am given a sufficient window of time to complete the assignments. 
Thus, the entire instrument should be condensed into those common fourteen items that should better reflect the construct, effective teaching, according to Chickering and Gamson's (1987) original Seven Principles, from the standpoint of student perceptions, which is what this study focuses upon. Moreover, those fourteen factors reflect what both male and female students agree to be important and beneficial to their learning.

\section{Limitations}

This study was limited by the relatively low response rate, given the large number of courses selected; thereby, raising potential concerns associated with non-respondent bias. The key issue was that the nature of the study dictated that the students in each course have the choice of not participating. Furthermore, the students were informed that their cooperation, or lack of it, would have no impact on their specific course grades or on the future of their instructor.

Thus, there was apparently a lack of sufficient motivation for a majority of the students to respond, and this presents a problem. The lower response rate in online evaluations is an issue that has been documented (Dommeyer, Baum, Hanna, \& Chapman, 2004; Dommeyer, Baum, \& Hanna, 2002; Nulty, 2008). Moreover, all three aforementioned authors concur that incentives should be offered to the students in order to boost the response, ranging from a raffle for the participants to a bonus grade in the course. While those were not practical alternatives for this study, future researchers should seriously consider those suggestions.

In addition, the ratio of three women to each man among respondents was not representative of the typical enrollment by sex in undergraduate online courses at this 
institution, and the reason for that was never clear. Thus, future studies should include an analysis of possible sex biases among students volunteering to participate and those who choose not to, to determine if sex acts as a motivator or a disincentive for volunteering.

\section{Summary}

This chapter offered a recapitulation of the evidence for validity of the Online Teaching Effectiveness Instrument (OTEI), followed by a discussion of the factor structure yielded by an exploratory factor analysis of the combined scores for the entire study, and finally a discussion of the factor structures yielded by separate analyzes of the scores for men and women.

The final instrument contained five factors. Four of those aligned with a corresponding number of original Chickering and Gamson's (1987) original Seven Principle. The fifth factor contained items from the remaining three principles. Thus, the original 27 items in the instrument were condensed into 14 items that afford a valid measurement of student perceptions of instructor performance in online courses. 


\section{REFERENCES}

Adelman, C., \& Reuben E. (1984). Starting with students: Promising approaches in American higher education. Retrieved from ERIC database. (ED257411)

Addison, W. E., Best, J., \& Warrington, J. D. (2006). Students' perceptions of course difficulty and their ratings of the instructor. College Student Journal, 40, 409-416.

Algozzine, B., Beattie, J., Bray, M., Flowers, C., Gretes, J., Howley, L., et al. (2004). Student evaluation of college teaching. College Teaching, 52, 134-41.

Allen, I. E., \& Seaman, J. (2005). Growing by degrees: Online education in the United States 2005. Needham, MA: Sloan Consortium.

Allen, I. E. \& Seaman, J. (2006). Making the grade: Online education in the United States, 2006. Needham, MA: Sloan Consortium.

Allen, I. E., \& Seaman, J. (2007). Online Nation: Five years of growth in online learning. Needham, MA: Sloan Consortium.

Allen, I. E., \& Seaman, J. (2010). Class differences: Online education in the United States, 2010. Needham, MA: Sloan Consortium.

Anderson, K. J., \& and Smith, G. (2005). Students' preconceptions of professors: Benefits and barriers according to ethnicity and gender. Hispanic Journal of Behavioral Sciences, 27, 184-201.

Arendale, D. R. (2005). Postsecondary peer cooperative learning programs: Annotated bibliography. Retrieved from ERIC database. (ED422778)

Arreola, R. A. (2000). Developing a comprehensive faculty evaluation system. Bolton MA: Anker.

Association of American Colleges and Universities. (2002). Greater expectations: A new vision for learning as a nation goes to college. Washington, DC: Author.

Astin, A. W. (1965). College preferences of very able students. College and University, 40, 282-297.

Astin, A. W. (1968). Undergraduate achievement and institutional excellence. Science, 161, 661-668.

Astin, A. W. (1971). Predicting academic performance in college. New York, NY: Macmillan.

Astin, A. W. (1975). Preventing students from dropping out. San Francisco: Jossey-Bass. 
Astin, A. W. (1985). Achieving educational excellence. San Francisco, CA: Jossey-Bass.

Baiocco, S. A., \& DeWaters, J. N. (1998). Successful college teaching: Problem-solving strategies of distinguished professors. Needham Heights, MA: Allyn \& Bacon.

Bangert, A. W. (2006). The development of an instrument for assessing online teaching effectiveness. Journal of Educational Computing Research, 35, 227-244.

Basow, S. A. (2000). Best and worst professors: Gender patterns in students' choices. Sex Roles: A Journal of Research, 43, 407-117.

Basow, S. A., \& Montgomery, S. (2005). Student ratings and professor self-ratings of college teaching: Effects of gender and divisional affiliation. Journal of Personnel Evaluation in Education, 18, 91-106.

Basow, S. A., \& Silberg, N. T. (1987). Student evaluations of college professors: Are female and male professors rated differently? Journal of Educational Psychology, $79,308-314$.

Beachler, J., \& Gyer-Culver, B. (1998). Trends in teaching and learning innovation.. Retrieved from ERIC database. (ED414988)

Belcheir, M. J. (2001). What predicts perceived gains in learning and satisfaction. Retrieved from ERIC database. (ED480921)

Best, J. (2006, April 14). From fad to worse. The Chronicle of Higher Education, p. B6.

Borstorff, P. C. \& Lowe, K. L. (2007). Student perceptions and opinions toward elearning in the college environment. Academy of Educational Leadership Journal, 11(2), 13-29.

Bowen, H. R. (1977). Investment in learning: The individual and social value of American higher education. San Francisco, CA: Jossey-Bass.

Braxton J. M., Eimers, M. T., \& Bayer A. E. (1996). The implications of teaching norms for the improvement of undergraduate education. The Journal of Higher Education, 67, 603-625.

Braxton, J. M., Milem, J. F., \& Sullivan, A. S. (2000). The influence of active learning on the college student departure process: Toward a revision of Tinto's theory. Journal of Higher Education, 71, 569-90.

Briane, M. W., Wong, E. H., \& Wiest, D. J. (1999). The effect of student-faculty interactin on college students' academic achievement and self concept. Education, $119,730-733$. 
Brown, R. (1979). Perceptions of teaching/learning style: The mediating process in tudent evaluation of instruction. CEDR Quarterly, 12(4), 16-18.

Bryant, F. B., \& Yarnold, P. R. (1995). Principal components analysis and exploratory and confirmatory factor analysis. In L. G. Grimm \& R R. Yarnold (Eds.), Reading and understanding multivariale statistics (pp. 99-136). Washington, DC: American Psychological Association.

Caboni, T. C., Mundy, M. E., \& Duesterhaus, M. B. (2002). The implications of the norms of undergraduate college students for faculty enactment of principles of good practice in undergraduate education. Peabody Journal of Education, 77, 125-137.

Campion, W. J., Mason, D. V., \& Erdmann, H. (2000). How faculty evaluations are used in Texas community colleges. Community College Journal of Research and Practice, 24, 169-179.

Carin, R. M., Kuh, G. D., \& Klein, S. P. (2006). Student engagement and student learning: testing the linkages. Research in Higher Education, 47, 1-32.

Cashin, W. E., \& Downey, R. G. (1992). Using global student rating items for summative evaluation. Journal of Educational Psychology, 84, 563-572.

Chatterji, M. (2003). Designing and using tools for educational assessment. Boston, MA: Allyn and Bacon.

Centra, J. A. (2003). Will teachers receive higher student evaluations by giving higher grades and less course work? Research in Higher Education, 44, 495-518.

Centra, J. A. (1993). Reflective faculty evaluation : Enhancing teaching and determining faculty effectiveness. San Francisco, CA: Jossey-Bass.

Centra, J. A., \& Gaubatz, N. B. (2000). Is there gender bias in student evaluations of teaching? Journal of Higher Education, 71, 17-33.

Chickering, A. W., \& Ehrmann, S. C. (1996). Implementing the seven principles: technology as lever. AAHE Bulletin, 49(2), 3-6.

Chickering, A. W., \& Gamson, Z. F.. (1987). Seven principles of good practice in undergraduate education Retrieved from ERIC database. (ED282491)

Chickering, A., \& Gamson, Z. (Eds.). (1991). Applying the seven principles for good practice in undergraduate education. San Francisco, CA: Jossey-Bass. 
Colbeck, C. L., Cabrera, A. F., \& Terenzini, P. T. (2000). Learning professional confidence: Linking teaching practices, students' self-perceptions, and gender. The Review of Higher Education, 24, 173-191.

Conceição, S. C. O. (2007). Understanding the environment for online teaching. New Directions for Adult and Continuing Education, 113, 5-11.

Cross, K.P. (1986, March). Taking teaching seriously. Presentation at the Annual Meeting of the American Association for Higher Education.

Cruce, T. M., Wolniak, G. C., Seifert, T. A., \& Pascarella, E. T. (2006). Impacts of good practices on cognitive development, learning orientations, and graduate degree plans during the first year of college. Journal of College Student Development, 9 , 365-383.

Cureton, E. E. (1956). Rank-biserial correlation. Psychometrika, 21, 287-290.

Cureton, E. E. (1968). Rank-biserial correlation - When ties are present. Educational and Psychological Measurement, 28, 77-79.

Dennen, V. P., Darabi, A. A., \& Smith, L. J. (2007). Instructor-Learner Interaction in Online Courses: The relative perceived importance of particular instructor actions on performance and satisfaction. Distance Education, 28, 65-79.

DeVellis, R. F. (2003). Scale development: Theory and applications. Thousand Oaks, CA: Sage.

Dilts, D. A., Haber, L. J., \& Bialik, D. (1994). Assessing what professors do: An introduction to academic performance appraisal in higher education. Westport, CT: Greenwood.

Dommeyer, C. J., Baum, P., \& Hanna, R. W. (2002). College students' attitudes toward methods of collecting teaching evaluations: InClass Versus On-Line. Journal of Education for Business, 78(1), 11-15.

Dommeyer, C. J., Baum, P., Hanna, R. W., \& Chapman, K. S. (2004). Gathering faculty teaching evaluations by in-class and online surveys: their effects on response rates and evaluations. Assessment \& Evaluation in Higher Education, 29, 611-623.

Dunn, R. (2000). Practical approaches to using learning styles in higher education In R. Dunn \& S. A. Griggs (Eds.), Practical approaches to using learning styles in higher education Westport (pp. 19-32). Westport, CT: Bergin \& Garvey.

Dunn, R. S., \& Dunn, K. J. (1979). Learning styles/teaching styles: Should they, can they, be matched. Educational Leadership, 36, 238-244. 
Dunn, R. S., \& Dunn, K. J. (1978). Teaching students through their individual learning styles: A practical approach. Mahwah, NJ: Erlbaum.

Dunn, R., Griggs, S. A., Olson, J., Gorman, B., \& Beasley, M.(1995). A metaanalytic validation of the Dunn and Dunn Learning-Styles Model. Journal of Educational Research, 88, 353-361.

Ehrmann, S. C. (1995). Asking the right questions. Change, 2(2), 20-27.

Eimers, M. T., Braxton J. M. \& Bayer A. E. (1998). The implications of teaching norms for the improvement of undergraduate education in teaching-oriented colleges. Retrieved from ERIC database. (ED427587)

Eom, S. B., Ketcherside, M. A., Lee, H., Rodgers, M. L. \& Starrett, D. (2004). The determinants of web-based instructional systems' outcome and satisfaction: an empirical investigation. In P. Darbyshire (Ed.), Instructional technologies: Cognitive aspects of online programs (pp. 96-140). Hershey PA: IRM.

Espasa, A. \& Meneses, J. (2010). Analysing feedback processes in an online teaching and learning environment: an exploratory study. Higher Education, 59, 277-292.

Ewell, P. T. \& Jones, D. P. (1996). Indicators of good practice in undergraduate education: a handbook for development and implementation Retrieved from ERIC database. (ED403 828)

Fries, C. J. \& McNinch, R. J. (2003). Signed versus unsigned student evaluations of teaching: A comparison. Teaching Sociology, 31, 333-344.

Gamson, Z. F. (1991). A brief history of the seven principles for good practice in undergraduate education. New Directions for Teaching and Learning, 47, 5-12.

Ganivet, F. (2002, February). Pilot survey study conducted during the Florida Community Colleges Distance Learning Consortium quarterly meeting, Santa Fe Community College, Gainesville, FL.

Gates, S. M., Augustine, C. H., Benjamin, R., Bikson, T. K., Kaganoff, T., Levy, D. G., Moini, J. S., \& Zimmer, R. W. (2002). Ensuring quality and productivity in higher education: an analysis of assessment practices. Retrieved from ERIC database. (ED466688)

Gay, L. R. \& Airasian, P. (2000). Educational research: Competencies for analysis and application (pp. 129-131). Upper Saddle River, NJ: Merrill/Prentice Hall.

Gerbing, D. W., \& Hamilton, J. G. (1996). Viability of exploratory factor analysis as a precursor to confirmatory factor analysis. Structural Equation Modeling, 3, 62-72. 
Gettinger, M. (1984). Achievement as a function of time spent in learning and time needed for learning. American Educational Research Journal, 21, 617-628.

Goldenberg, C. (1992). The limits of expectations: A case for case knowledge about teacher expectancy effects. American Educational Research Journal, 29, 517-544.

Graham, C., Cagiltay, K., Craner, J., Lim, B., \& Duffy, T. M. (2000). Teaching in a web based distance learning environment: An evaluation summary based on four courses (CRLT Technical Report No. 13-00). Bloomington, IN: Indiana University.

Graham, C., Cagiltay, K., Lim, B., Craner, J., \& Duffy, T. M. (2001, March-April). Seven principles of effective teaching: a practical lens for evaluating online courses. Technology Source. Retrieved from http://www. technologysource.org/article/seven_principles_of_effective_teaching.

Graunke, Steven S., \& Woosley, S. A. (2005). An exploration of the factors that affect the academic success of college sophomores. College Student Journal, 39, 36776.

Greenwald, A. G. (1997). Validity concerns and usefulness of student ratings of instruction. American Psychologist, 52, 1182-1186.

Greenwald, A. G., \& Gillmore, G. M. (1997). No pain, no gain? The importance of measuring course workload in student ratings of instruction. Journal of Educational Psychology, 89, 743-751.

Griffin, B. W. (2004). Grading leniency, grade discrepancy, and student ratings of instruction. Contemporary Educational Psychology, 29, 410-425.

Guinn, B., \& Vincent, V. (2006). The influence of grades on teaching effectiveness ratings at a Hispanic-serving institution. Journal of Hispanic Higher Education, 5, $313-321$

Hara, N. \& Kling, R. (2001). Educause Quarterly, 3, 68-69.

Heckert, T. M., Latier, A, Ringwald-Burton, A., \& Drazen, C. (2006). Relations among student effort, perceived class difficulty appropriateness, and student evaluations of teaching: Is it possible to "buy" better evaluations through lenient grading? College Student Journal, 40, 588-596.

Herbert, A. W. (1999, March 8). Chancellor's memorandum CM-C-13.00-03/99. Board of Governors, State University System of Florida. Retrieved from http://www.flbog.org/chn/cm/cm-c-13.pdf. 
Hinkle, D. E., Wiersma, W., \& Jurs, S. G. (2003). Applied statistics for the behavioral sciences $\left(5^{\text {th }}\right.$ ed.). Boston, MA: Houghton Mifflin.

Hobson, S. M., \& Talbot, D. M. (2001). Understanding student evaluations: What all faculty should know. College Teaching 49, 26-31.

Hunter, W. E. (1980). Relationship between learning styles, grades, and student ratings of instruction. Community/Junior College Research Quarterly, 5, 73-84.

Isely, P., \& Singh, H. (2005). Do higher grades lead to favorable evaluations? Journal of Economic Education, 36, 29-42.

Jiang, M., \& Ting, E. (1999). A study of students' perceived learning in a web-based online environment. Retrieved from ERIC database. (ED448721)

Jose, J., \& Cody, J. (1971). Teacher-pupil interaction as it relates to attempted changes in teacher expectancy of academic ability and achievement. American Educational Research Journal, 8, 39-49.

King, C. P. (1998). A validation study of an instrument designed to measure teaching effectiveness. Journal of Social Work Education 34, 261-271

Kline, P. (1979). Psychometrics and psychology. London, UK: Acaderric Press.

Knapper, C. (2001) Broadening our approach to teaching evaluation. New Directions for Teaching and Learning, 88, 3-9.

Koljatic, M., \& Kuh, G. D. (2001). A longitudinal assessment of college student engagement in good practices in undergraduate education. Higher Education, 42, 351-371.

Krank, H. M., \& Moon, C. E. (2001). Can a combined mastery/cooperative learning environment positively impact undergraduate academic and affective outcomes? Journal of College Reading and Learning 31, 195-208.

Kuh, G. D., \& Hu, S. (2001). The effects of student-faculty interaction in the 1990s. The Review of Higher Education, 24, 309-332.

Kuh, G. D. Laird, T. F. \& Umbach, P. D. (2004). Aligning faculty activities \& student behavior: Realizing the promise of greater expectations. Liberal Education, 90(4), 24-31.

Kuh, G. D., Pace, R. C., \& Vesper, N. (1997). The development of process indicators to estimate student gains associated with good practices in undergraduate education. Research in Higher Education, 38, 435-454. 
Laird, T. F., Shoup, R., Kuh, G. D., \& Schwarz, M. J. (2008). The effects of discipline on deep approaches to student learning and college outcomes. Research in Higher Education, 49, 469-494.

Lesser, D., \& Ferrand, J. (2000) Effect of class size, grades given, and academic field on student opinion of instruction. Community College Journal of Research and Practice, 24, 269-277.

Maddux, C., \& Cummings, R. (2004). Fad, fashion, and the weak role of theory and research in information technology in education. Journal of Technology and Teacher Education, 12, 511-533.

Manus, A. L. (1996). Procedural versus constructivist education: A lesson from history. The Educational Forum, 60, 312-316.

Marsh, H. W., \& Bailey, M. (1993). Multidimensional students' evaluations of teaching effectiveness: A profile analysis. Journal of Higher Education, 64, 1-18.

Marsh, H. W. \& Roche, L. A. (2000). Effects of grading leniency and low workload on students' evaluations of teaching: Popular myth, bias, validity, or innocent bystanders? Journal of Educational Psychology, 92, 202-228.

Marsh, H. W. \& Roche, L. A. (1997). Making students' evaluations of teaching effectiveness effective: The critical issues of validity, bias, and utility. American Psychologist, 52, 1187-1197.

Matthews, W. J. (2003). Constructivism in the classroom: Epistemology, history, and empirical evidence. Teacher Education Quarterly, 30, 51-64.

Merisotis, J. P. (2001). Quality and equality in Internet-based higher education: benchmarks for success. Retrieved from ERIC database..(ED469341)

Miller, M. A. (2005). AAHE's legacy. Change, 37(5), 8-20.

Miller, R. I. (1987). Evaluating faculty for promotion and tenure. San Francisco, CA: Jossey-Bass.

Morris, L. V., Finnegan, C., \& Wu. S. (2005). Tracking student behavior, persistence, and achievement in online courses. Internet and Higher Education 8, 221-231.

Nonis, S. A., \& Hudson, G. I. (2006). Academic performance of college students: Influence of time spent studying and working. Journal of Education for Business, 81, 151-159.

Nulty, D. D. (2008). The adequacy of response rates to online and paper surveys: what can be done? Assessment \& Evaluation in Higher Education, 33, 301-314. 
Nunnally, J. C. (1978). Psychometric theory (2nd ed.). New York, NY: McGraw-Hill.

Olivares, O. J. (2001). Student interest, grading leniency, and teacher ratings: A conceptual analysis. Contemporary Educational Psychology 26, 382-399.

Ory, C. J. (2000). Teaching evaluation: past, present, and future. New Directions for Teaching and Learning, 83, 13-18.

Paechter, M., Maier, B., \& Macher, D. (2010). Students' expectations of, and experiences in e-learning: Their relation to learning achievements and course satisfaction. Computers \& Education, 54, 222-229.

Phipps, R. \& Merisotis, J. (2000). Quality on the line: Benchmarks for success in Internet-based distance education Retrieved from ERIC database. (ED444407)

Rathert, G. H., \& Reed, D. (2001). The effectiveness of electronically communicated encouragement on student performance. Retrieved from ERIC database. (ED471187)

Redmon, K. D. (1999). Faculty evaluation: A response to competing values. Community College Review, 27, 57-71.

Richardson, V. (2003). Constructivist pedagogy. Teachers College Record, 105, 16231640.

Rosenthal, R. \& Jacobson, L. (1968). Pygmalion in the classroom: Teacher expectations and pupils' intellectual development. New York, NY: Holt, Rinehart , \& Winston.

Russell, T L. (1999). The no significant difference phenomenon. Chapel Hill: North Carolina State University, Office of Instructional Telecommunications.

Ryan, J. F. (2005). Big can be great: Enhancing undergraduate education at researchextensive universities. Retrieved from ERIC database. (ED491036)

Schwarz, R. H., \& Cook, S. S. (1972 ). Teachers' expectancy as it relates to the academic achievement of EMR students. Journal of Educational Research, 65, 393-396.

Shea, P., Fredericksen, E., Pickett, A., Pelz, W., \& Maher, G. (2000). Building knowledge building communities: Consistency, contact and communication in the virtual classroom. Journal of Educational Computing Research, 23, 359-83.

Sheehan, E. P., \& DuPrey, T. (1999). Student evaluations of university teaching. Journal of Instructional Psychology, 23, 188-193. 
Sher, A. (2009). Assessing the relationship of student-instructor and student-student interaction to student learning and satisfaction in web-based online learning environment. Journal of Interactive Online Learning, 8, 102-120.

Smith, G. G., Ferguson, F. \& Caris, M. (2001). Online vs face-to-face. $T$ H E Journal, 28(9), 18-22, 24, 26.

Sorcinelli, M. D. (1991). Research findings on the seven principles. New Directions for Teaching and Learning, 47, 13-25.

Southern Association of Colleges and Schools. (2000). Best practices for electronically offered degree and certificate programs. Retrieved from http://www.sacscoc.org/pdf/commadap.pdf

Spaulding, K., \& Dwyer, F. (2001). The effect of time-on-task when using job aids as an instructional strategy. International Journal of Instructional Media, 28, 437-447.

Stage, F. K., Muller, P. A. Kinzie, J. \& Simmons, A. (1998). Creating learning centered classrooms: What does learning theory have to say? Retrieved from ERIC database. (ED422778)

Sullivan, M. (1998). Analysis of student field dependent status, attitude toward the technology medium, and perception of interaction in a distance education setting: implications for improving the quality of distance education Retrieved from ERIC database. (ED419532)

Theall, F., \& Franklin, J. (2000). Creating responsive student ratings systems to improve evaluation practice. New Directions for Teaching and Learning, 83, 95-107.

U. S. Department of Education. (1983). A nation at risk: The imperative for educational reform (The National Commission on Excellence in Education). Washington, D.C: Author.

U. S. Department of Education. (1984). Involvement in learning: Realizing the potential of American higher education. Final report of the Study Group on the conditions of Excellence in American Higher Education. Retrieved from ERIC database. (ED246833)

Wright, R.E. (2006). Student evaluations of faculty: Concerns raised in the literature, and possible solutions. College Student Journal, 40, 417-422.

Yiping, L. R., Bernard, M., \& Abrami, P. C. (2006). Media and pedagogy in undergraduate distance education: a theory-based meta-analysis of empirical literature. Educational Technology Research and Development, 54, 141-76. 
Young, S. (2006). Student views of effective online teaching in higher education. American Journal of Distance Education, 20, 65-77. 
Appendix A

The Online Teaching Effectiveness Instrument 


\section{Online Teaching Effectiveness Instrument}

1. My sex is: $\quad$ Male $\square \quad$ Female

2. My instructor's sex is: $\quad$ Male $\square \quad$ Female $\square \quad$ I don't know

Questions 3 to 28 will require the following choice of responses:

Strongly disagree $\square \quad$ Disagree $\square \quad$ Agree $\square \quad$ Strongly agree

Encourages contacts between students and faculty

3. My instructor is very accessible through email.

4. I have a good idea of how long it will take the instructor to respond to my messages.

5. I am satisfied with the instructor's response time to my messages.

Develops reciprocity and cooperation among students

6. The instructor encourages contact between students in this course.

7. The course bulletin or public message board is useful for exchanging information with other people taking the course.

8. I am familiar with the work that some of the other students have done in this course.

9. The instructor encourages students to help each other in this course.

10. Some of my fellow students have been very supportive of me in this course.

$\underline{\text { Uses active learning techniques }}$

11. I have learned new things by doing them, not just by reading about them.

12. I have learned new things by conducting independent research.

13. I believe that the assignments in this course help me learn useful things.

14. The links to other information provided in this course have been helpful to me.

\section{Gives prompt feedback}

15. I can easily find out when all the assignments are due.

16. I have received my grades for quizzes and assignments promptly.

17. I am satisfied with the instructor's turnaround time for the assignments. 
18. The instructor offers useful feedback.

\section{Emphasizes time on task}

19. There is enough work in this course to keep me busy for three hours per week.

20. I believe my instructor has a way of knowing how much time I spend in this course.

21. I believe that my instructor values hard work.

\section{Communicates high expectations}

22. I think I know what my instructor expects of me in this course.

23. I have worked hard in this course to meet my instructor's expectations.

24. The syllabus is clear about all the work that I have to do throughout the course.

\section{$\underline{\text { Respects diverse talents and ways of learning }}$}

25. In this course I am comfortable in expressing my own points of view.

26. I have found review materials (e.g., practice quizzes) provided in this course to be helpful.

27. I am given a sufficient window of time to complete the assignments.

28. In this course I have learned in other ways than by just reading the text.

29. The workload in this course has been: Easy $\square \quad$ Average $\square \quad$ Demanding

Extreme

30. For a final grade in this course I expect an: A $\square \quad$ B $\square \quad$ C $\square \quad$ D $\quad F \quad F$ 
Appendix B

The Online Teaching Effectiveness Instrument Seven-Factor Solution Rotated Matrix 
The Online Teaching Effectiveness Instrument Seven-Factor Solution Rotated Matrix

\begin{tabular}{|c|c|c|c|c|c|c|c|}
\hline Item & Factor 1 & Factor 2 & Factor 3 & Factor 4 & Factor 5 & Factor 6 & Factor 7 \\
\hline I19 & .821 & .025 & .161 & .065 & .164 & -.224 & .113 \\
\hline $\mathrm{I} 27$ & .740 & .223 & .147 & .164 & .099 & .183 & .216 \\
\hline $\mathrm{I} 15$ & .730 & .074 & .197 & .117 & .172 & .412 & .021 \\
\hline $\mathrm{I} 24$ & .661 & .058 & .210 & .175 & .288 & .388 & -.075 \\
\hline I7 & .590 & .490 & .241 & .067 & .222 & .176 & .000 \\
\hline $\mathrm{I} 25$ & .542 & .252 & .033 & .491 & .265 & .183 & .065 \\
\hline I11 & .527 & .320 & .139 & .296 & .058 & .070 & .512 \\
\hline $\mathrm{I} 13$ & .471 & .300 & .114 & .385 & .180 & .185 & .462 \\
\hline I9 & .178 & .798 & .136 & .207 & .118 & .143 & .088 \\
\hline $\mathrm{I} 10$ & .082 & .792 & -.035 & -.001 & .094 & .111 & .282 \\
\hline I8 & .063 & .761 & .124 & .190 & .018 & -.091 & .184 \\
\hline I6 & .533 & .591 & .341 & .059 & .057 & .021 & -.022 \\
\hline $\mathrm{I} 4$ & .066 & .169 & .807 & .234 & .120 & .312 & .061 \\
\hline I5 & .419 & .129 & .788 & .129 & .135 & .129 & .147 \\
\hline $\mathrm{I} 3$ & .425 & .111 & .763 & .042 & .133 & .170 & .125 \\
\hline $\mathrm{I} 28$ & .209 & .088 & .175 & .842 & .107 & .071 & .145 \\
\hline I14 & .059 & .375 & .208 & .587 & .158 & .205 & .361 \\
\hline I26 & .162 & .152 & .031 & .519 & .296 & .458 & .273 \\
\hline $\mathrm{I} 23$ & .273 & .048 & .046 & .099 & .845 & -.011 & .162 \\
\hline $\mathrm{I} 22$ & .198 & .159 & .176 & .166 & .842 & .189 & .060 \\
\hline $\mathrm{I} 21$ & .060 & .112 & .359 & .286 & .532 & .433 & .150 \\
\hline I17 & .170 & .060 & .333 & .193 & .118 & .786 & .161 \\
\hline I16 & .567 & .006 & .367 & .039 & .000 & .574 & .101 \\
\hline I18 & .134 & .250 & .414 & .475 & .273 & .492 & .016 \\
\hline I12 & .017 & .311 & .101 & .173 & .138 & .120 & .770 \\
\hline $\mathrm{I} 20$ & .388 & .202 & .253 & .206 & .297 & .075 & .433 \\
\hline
\end{tabular}


Appendix $\mathrm{C}$

The Online Teaching Effectiveness Instrument Seven-Factor Solution Rotated Matrix for Female Students 


\begin{tabular}{|c|c|c|c|c|c|c|c|}
\hline \multicolumn{8}{|c|}{$\begin{array}{c}\text { The Online Teaching Effectiveness Instrument Seven-Factor Solution } \\
\text { Rotated Matrix for Female Students }\end{array}$} \\
\hline Item & Factor 1 & Factor 2 & Factor 3 & Factor 4 & Factor 5 & Factor 6 & Factor 7 \\
\hline I19 & .784 & .061 & -.305 & .165 & .206 & .108 & .127 \\
\hline $\mathrm{I} 15$ & .781 & .028 & .361 & .176 & .184 & .046 & .074 \\
\hline $\mathrm{I} 27$ & .770 & .254 & .192 & .090 & .023 & .230 & .053 \\
\hline $\mathrm{I} 24$ & .700 & -.016 & .315 & .292 & .306 & .026 & .177 \\
\hline I16 & .621 & .031 & .517 & .301 & .028 & -.035 & .033 \\
\hline I7 & .618 & .461 & .108 & .217 & .175 & .141 & .007 \\
\hline $\mathrm{I} 25$ & .528 & .276 & .253 & .013 & .233 & .246 & .424 \\
\hline $\mathrm{I} 13$ & .492 & .412 & .274 & .042 & .183 & .488 & .173 \\
\hline I11 & .491 & .407 & .112 & .193 & .081 & .406 & .316 \\
\hline I8 & .054 & .812 & -.012 & .156 & .054 & .126 & .137 \\
\hline I9 & .191 & .796 & .251 & .022 & .096 & .137 & .079 \\
\hline $\mathrm{I} 10$ & .057 & .792 & .051 & .059 & .051 & .215 & .095 \\
\hline I6 & .554 & .609 & .031 & .260 & .037 & .041 & -.029 \\
\hline $\mathrm{I} 17$ & .242 & .014 & .798 & .319 & .018 & .113 & .101 \\
\hline $\mathrm{I} 18$ & .151 & .269 & .647 & .378 & .237 & .149 & .253 \\
\hline $\mathrm{I} 21$ & .072 & .097 & .590 & .310 & .453 & .307 & .006 \\
\hline $\mathrm{I} 26$ & .166 & .256 & .578 & .058 & .280 & .219 & .367 \\
\hline $\mathrm{I} 14$ & .132 & .499 & .510 & .043 & .084 & .442 & .191 \\
\hline I4 & .059 & .150 & .375 & .805 & .087 & .104 & .209 \\
\hline I5 & .429 & .174 & .173 & .774 & .090 & .159 & .083 \\
\hline $\mathrm{I} 3$ & .418 & .121 & .174 & .760 & .088 & .135 & -.036 \\
\hline $\mathrm{I} 23$ & .225 & .054 & .007 & .046 & .860 & .159 & .133 \\
\hline $\mathrm{I} 22$ & .204 & .144 & .290 & .114 & .837 & .105 & .052 \\
\hline $\mathrm{I} 12$ & .021 & .296 & .152 & .144 & .130 & .757 & .163 \\
\hline $\mathrm{I} 20$ & .365 & .209 & .145 & .203 & .238 & .646 & .034 \\
\hline $\mathrm{I} 28$ & .191 & .253 & .283 & .191 & .141 & .193 & .785 \\
\hline
\end{tabular}




\section{Appendix D}

The Online Teaching Effectiveness Instrument Seven-Factor Solution Rotated Matrix for Male Students 
The Online Teaching Effectiveness Instrument Seven-Factor Solution Rotated Matrix for Male Students

\begin{tabular}{|c|c|c|c|c|c|c|c|}
\hline Item & Factor 1 & Factor 2 & Factor 3 & Factor 4 & Factor 5 & Factor 6 & Factor 7 \\
\hline $\mathrm{I} 4$ & .843 & -.017 & .190 & .173 & .258 & .150 & .044 \\
\hline I5 & .801 & .354 & .158 & .029 & .112 & .221 & .127 \\
\hline $\mathrm{I} 3$ & .767 & .405 & .144 & .088 & .196 & .159 & .096 \\
\hline $\mathrm{I} 16$ & .582 & .440 & .116 & -.042 & .535 & -.149 & .041 \\
\hline I6 & .536 & .418 & -.018 & .451 & .117 & .211 & -.285 \\
\hline I7 & .427 & .411 & -.021 & .425 & .359 & .323 & -.227 \\
\hline I19 & .188 & .826 & .096 & .037 & .049 & .185 & .153 \\
\hline $\mathrm{I} 27$ & .312 & .690 & .234 & .155 & .185 & .310 & .001 \\
\hline $\mathrm{I} 11$ & .065 & .629 & .495 & .374 & .091 & -.055 & .026 \\
\hline $\mathrm{I} 15$ & .375 & .550 & .075 & .123 & .489 & .102 & -.063 \\
\hline $\mathrm{I} 14$ & .328 & $-4.429 \mathrm{E}-5$ & .752 & .161 & -.036 & .256 & .180 \\
\hline $\mathrm{I} 28$ & .109 & .165 & .699 & -.206 & .152 & .248 & .063 \\
\hline $\mathrm{I} 26$ & .023 & .164 & .657 & .028 & .411 & .249 & .082 \\
\hline $\mathrm{I} 13$ & .196 & .447 & .630 & .219 & .220 & .086 & -.016 \\
\hline $\mathrm{I} 12$ & -.005 & .051 & .619 & .531 & -.002 & -.125 & -.186 \\
\hline $\mathrm{I} 10$ & -.081 & .073 & -.016 & .842 & .214 & .094 & -.035 \\
\hline I8 & .143 & .097 & .133 & .766 & -.124 & .133 & .292 \\
\hline I9 & .381 & .167 & .111 & .747 & .120 & .165 & .014 \\
\hline $\mathrm{I} 17$ & .356 & .044 & .260 & .152 & .717 & .126 & .233 \\
\hline $\mathrm{I} 24$ & .237 & .506 & .065 & .059 & .649 & .219 & .070 \\
\hline $\mathrm{I} 18$ & .438 & .032 & .383 & .136 & .543 & .355 & -.109 \\
\hline $\mathrm{I} 25$ & .034 & .472 & .172 & .103 & .512 & .429 & -.140 \\
\hline $\mathrm{I} 22$ & .263 & .115 & .177 & .210 & .220 & .815 & .115 \\
\hline $\mathrm{I} 23$ & .108 & .283 & .227 & .106 & .054 & .790 & -.020 \\
\hline $\mathrm{I} 21$ & .338 & .082 & .295 & .096 & .388 & .505 & .363 \\
\hline $\mathrm{I} 20$ & .185 & .492 & .169 & .276 & $.316^{\prime \prime} 1$ & 111 & .566 \\
\hline
\end{tabular}


VITA

\title{
FERNANDO GANIVET
}

\author{
Born, Habana, Cuba
}

1973

B. A., Mass Communication

University of Miami

Coral Gables, Florida

1998

M. S., Mass Communication

Florida International University

Miami, Florida

2000-Present

Adjunct Instructor

Florida International University

Miami, Florida

1997-Present

Adjunct Instructor

Miami-Dade College

Miami, Florida

2000-2011

Doctoral Candidate in Higher Education

Florida International University

Miami, Florida 